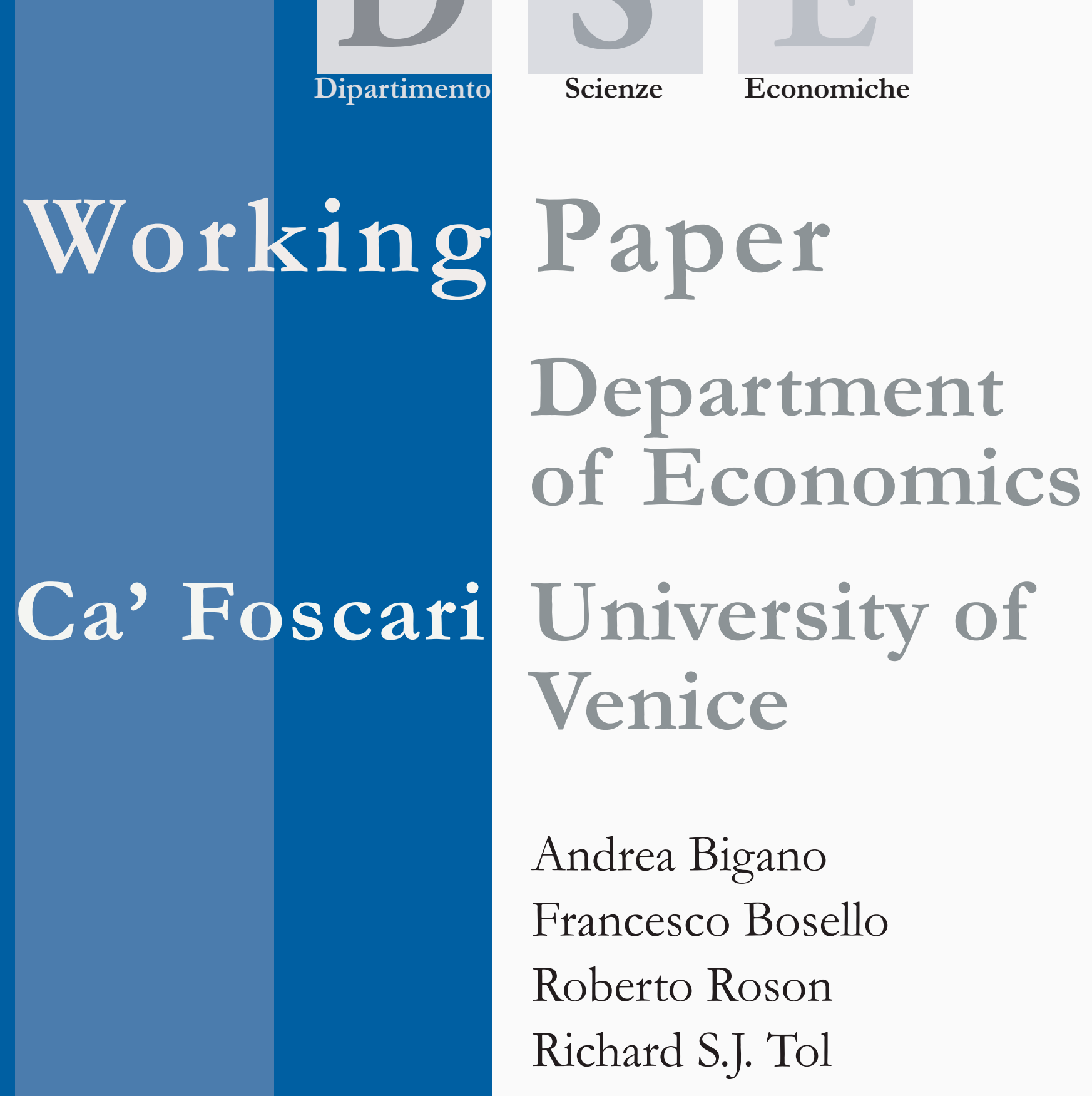

Economy-Wide Impacts of

Climate Change: a Joint Analysis for Sea Level Rise and Tourism 


\title{
ECONOMY-WIDE IMPACTS OF CLIMATE CHANGE: A JOINT ANALYSIS FOR SEA LEVEL RISE AND TOURISM
}

\author{
Andrea Bigano \\ Fondazione Eni Enrico Mattei, Italy \\ Francesco Bosello \\ Milan University and Fondazione Eni Enrico Mattei, Italy \\ Roberto Roson \\ Ca' Foscari University, Venice, and Fondazione Eni Enrico Mattei, Italy \\ Richard S.J. Tol \\ Hamburg University, Vrije Universiteit, Amsterdam, and Carnegie Mellon University, \\ Pittsburgh, PA, USA
}

\begin{abstract}
While climate change impacts on human life have well defined and different origins, the interactions among the diverse impacts are not yet fully understood. Their final effects, however, especially those involving social-economic responses, are likely to play an important role. This paper is one of the first attempts to disentangle and highlight the role of these interactions. It focuses on the economic assessment of two specific climate change impacts: sea-level rise and changes in tourism flows. By using a Computable General Equilibrium (CGE) model the two impacts categories are first analysed separately and then jointly. Considered separately, in 2050, the forecasted $25 \mathrm{~cm}$. of sea level rise imply a GDP loss ranging from (-) $0.1 \%$ in South East Asia to almost no loss in Canada, while redistribution of tourism flows - which in terms of arrivals favours Western Europe, Japan, Korea and Canada and penalises all the other world regions - triggers GDP losses ranging from (-) $0.5 \%$ in Small Island States to (-) $0.0004 \%$ in Canada. GDP gainers are Australia, New Zealand, Western Europe, Middle East and South Asia.
\end{abstract}

\section{Keywords}

Climate change, Sea level rise, Tourism, Computable General Equilibrium Models

\section{JEL Codes}

C68, D58, Q25

Address for correspondence: Roberto Roson Department of Economics Ca’ Foscari University of Venice Cannaregio 873, Fondamenta S.Giobbe 30121 Venezia - Italy Phone: (++39) 041234147 Fax: (++39) 0412349176 e-mail: roson@unive.it

This Working Paper is published under the auspices of the Department of Economics of the Ca' Foscari University of Venice. Opinions expressed herein are those of the authors and not those of the Department. The Working Paper series is designed to divulge preliminary or incomplete work, circulated to favour discussion and comments. Citation of this paper should consider its provisional character.

The Working Paper Series is availble only on line (www.dse.unive.it/pubblicazioni) For editorial correspondence, please contact:
Department of Economic

Ca' Foscari University of Venice

Cannaregio 873, Fondamenta San Giobbe

30121 Venice Italy

Fax: ++390412349210 


\section{Introduction}

Of the many impacts of climate change, sea level rise is often seen as one of the most threatening. The impacts of sea level rise are straightforward - more coastal erosion and sea floods, unless costly adaptation measures are undertaken - and unambiguously negative. Sea level rise could have very substantial impacts on river deltas, on coastal zones which are often more densely populated and have more infrastructures, and may wipe out entire islands and island nations (Nichols et al., 2007).

Sea level rise is therefore one of the most prominent assessments of the impacts of climate change, and the costs of sea level rise are equally prominent in the estimates of the costs of climate change.

In 1991 the IPCC had already proposed methodologies and estimates of the cost of sea level rise and of the benefit of coastal protection (IPCC CZMS, 1991). This issue was subsequently investigated in a very large body of literature. The majority of studies is based on engineering researches and on the Geographical Information System (GIS) assessing the area and subsequently people and activities at risk, to which an economic value is attached. This figure is the base to which the cost of coastal protection can be compared for a cost-benefit analysis (Nicholls et al., 2007). Studies in this vein include investigation at the world level with macro regional and country detail (see e.g. Hoozemans et al., 1993; Fankhauser, 1998, Tol, 2002; 2006), at the macro-regional level (see e.g. Fankhauser, (1994); Yohe et al. (1996); Yohe and Schlesinger, (1998) for the USA; Nicholls and Klein, (2003); CEC, (2007), for Europe), at the country level (see e.g. Dennis et al., (1995) for Senegal, Volonte and Nicholls, (1995) for Uruguay, Volonte and Arismendi, (1995) for Venezuela, Morisugi et al. (1995) for Japan, Zeider (1997) for Poland) and at the site level (see e.g. Gambarelli and Goria 
(2004) for the Fondi plane in Italy, Breil et al. (2005) for the city of Venice, Smith and Lazo (2001) analysing among others the Estonian cities of Tallin and Pärnu, and the Zhujian Delta in China, Saizar (1997) for Montevideo).

This vast literature concentrates on the direct costs of sea level rise and of possible adaptation options. The main result of these studies is that the cost of sea level rise (albeit in some cases a small fraction of GDP) can be considerably high in absolute terms. As an example, US\$ 0.06 billions is the estimated annuitised cost of $50 \mathrm{~cm}$. of sea level rise for the US according to Yohe et al. (1996). US\$ 3.4 billions is Morisugi et al, (1995) estimate for Japan. A yearly cost ranging from Euros 4.4 to 42.5 billions is the evaluation proposed for Europe by CEC (2007) for a sea level increase of 22 and $96 \mathrm{~cm}$., respectively. The Netherlands, Germany and Poland are expected to suffer a cumulated undiscounted capital loss of US\$186, 410 and 22 billions for 1 meter of sea level rise according to Nicholls and Klein (2003). Against this background, coastal protection seems to be not only effective, but also efficient in most cases. This is for instance confirmed for Europe as a whole (CEC, 2007), for the Netherlands, Germany (Klein, 2003), Poland (Zeider, 1997; Klein, 2003), for Japan (Morisugi et al., 1995) Senegal (Dennis et al. 1995). Tol (2007), showed, that high levels of coastal protection $(>70 \%$ of the threatened coast) would be optimal for the majority of the world's regions. However, for some countries or sites the efficient level of coastal protection is likely to be low or even zero, pointing out the importance of carefully evaluating benefits and costs of different options for sea level rise adaptation. This could be for instance the case of Dar es Salaam and of the entire populated coastline of Tanzania (Smit and Lazo, 2001), Uruguay (Volonte and Nicholls, 1995) or Venezuela (Volonte and Arismendi, 1995). 
The cited studies are however based on a direct costing approach: they basically evaluate costs multiplying a quantity loss (land or capital) or "displaced" (people), by the unitary "price" of the item lost or of the displacement. By contrast, only few papers attempted to assess the "higher-order" impacts of sea level rise and coastal protection. The issue here is to consider explicitly the goods' and factors' substitution mechanisms triggered by changes in relative prices responding to an initial land and property loss or to investment in coastal protection and their final effects on welfare or GDP.

Deke et al. (2002) do this using a recursive dynamic CGE model to estimate economy-wide implications of sea level rise, but they restrict the study to the costs of coastal protection, ignoring land loss and its wider economic consequences. The costs of coastal protection are subtracted from investment and, as they use a Solow-Swan growth engine to drive their recursive dynamic, this essentially reduces the capital stock, and hence economic output. However the stimulus to the engineering sector from investing in dikes and seawalls is neglected.

Darwin and Tol (2001) use a static CGE model. They consider both the cost of sea level rise in a no protection scenario and that of "optimal" coastal protection modelled as an instantaneous loss of productive capital. Like Deke et al. (2002), Darwin and Tol (2001) ignore the induced demand of coastal protection, thus probably overstating the impact of sea level rise. "Their" direct protection cost is composed of the cost of protection proper, and of fixed capital and land lost.

According to Deke et al., (2002) the direct protection costs against the $13 \mathrm{~cm}$. of sea level rise forecasted for 2030, are a tiny percentage of GDP, ranging from $0.001 \%$ in Latin America to $0.035 \%$ in India. However, coastal protection investment reduces "productive" capital stock and the input substitution processes 
triggered by capital scarcity imply a welfare loss ranging from $0.3 \%$ of India to $0.006 \%$ of Western Europe with respect to the no protection case. The study also highlights the different results produced when countries are ranked according to direct costs or welfare losses. This is because of the redistribution of regional as well as international allocation effects of a slightly lower path of investment.

In the no protection case, Darwin and Tol, (2001) estimate the annuitised total cost for $50 \mathrm{~cm}$. of sea level rise in 2100 of nearly US\$ 66 billions. The highest losses among OECD countries are the nearly US\$ 7 billions of Europe. Asian economies as a whole would lose US\$ 42 Billions. With an optimal protection policy direct costs are US\$ 4.4 billions for the world as a whole. In developed regions they are fairly small, ranging from almost nothing to $0.009 \%$ of total 1990 expenditures. In developing countries they reach the highest level in the China-South KoreaTaiwan-Hong Kong region where they amount to $0.1 \%$ of 1990 expenditure. Welfare effects in the protection case highlight a total loss of US\$ 4.9 billions, approximately 13\% higher than world direct cost. The additional losses are not equally distributed: in general, international trade tends to redistribute losses from regions with relatively high to regions with relatively low damages.

Climate change plays an obvious role in tourist destination choice as well. Although climate is by no means the only determinant of holiday destination choice (Crouch, 1995; Witt and Witt, 1995; Gossling and Hall, 2006a,b; Bigano et al., 2006a; Rosello et al., 2005), the "amenity of climate" is recognised as one of the major determinants of tourism flows (Maddison, 2001; Lise and Tol, 2002; Bigano et al., 2006b). The Mediterranean in particular benefits from this determinant, being close to the main holidaymakers of Europe's wealthy, but cool and rainy, 
Northwest. Tropical islands are another example, where in the recipe of a dream holiday their "perfect" climate is a fundamental ingredient.

Climate change would alter that, as tourists are particularly footloose. The currently popular holiday destinations may become too hot, and destinations that are currently too cool would see a surge in their popularity (Hamilton et al., 2005a,b; Hamilton and Tol, 2007; Amelung et al., 2007). Low ski resorts and winter tourism may be particularly vulnerable (Elsasser and Burki, 2002; Scott et al., 2004; 2007; OECD, 2007). This could have a major impact on some economies. Just consider that about $10 \%$ of world GDP is now spent on recreation and tourism, and that recent contributions highlight the importance of tourism in stimulating economic growth (Lee and Chang, 2008).

In two previous papers, Bosello et al. (2004) and Berrittella et al. (2006), we analysed the impact on the world economic system of, respectively, climate-change induced increase in sea level and change in tourism flows. Both studies are characterised by the use of CGE models, which allow assessing the "systemic" effects induced by changes in resources, technologies and consumption patterns. There are no other papers that look at the general equilibrium effects of climate change on tourism. Darwin and Tol (2001) and Deke et al. (2001) study the general equilibrium effects of sea level rise, but not as comprehensively as Bosello et al. (2004).

In this paper, we follow the same approach for a joint analysis of climate change impacts on tourism and sea level. Combining the two impact studies into a single, integrated analysis provides two main advantages: (1) the possibility of highlighting the complex interactions between the two adjustment processes; and (2) the potential for considering a direct effect of sea level rise on 
tourism destination choices. Jorgenson et al. (2004) and Kemfert (2002) study the combined impacts of climate change using a computable general equilibrium model, but they do not look at the impacts separately - and therefore do not estimate the interaction. Besides, Jorgenson et al. (2004) is limited to the USA, while neither Jorgenson et al. (2004) nor Kemfert (2002) includes tourism. Fankhauser and Tol (1996) first lamented the lack of integration between the different impacts of climate change, a point repeated by Tol et al. (2000) and Tol (2005); this is the first study of the economic interactions between the impacts of climate change.

In addition, this paper improves upon the two previous studies, in terms of methodology: an updated data base is used, to compute land losses; a more detailed geographical disaggregation is adopted (16 regions instead of 8 ) and a new procedure to model demand shifts in tourism destination choices is introduced.

In what follows section 2 describes the setting up of the benchmark for our CGE model, section 3 briefly introduces the sources for climate change impacts, section 4 describes the simulation exercises, section 5 presents results, finally section 6 concludes.

\section{Economic model and benchmark}

This study has been conducted through an unconventional use of a multi-country world CGE model: the Global Trade Analysis Project (GTAP) model (Hertel, 1996), in the version modified by Burniaux and Truong (2002), and subsequently extended by ourselves. ${ }^{\mathrm{i}}$

First, benchmark data-sets for the world economy at some selected future years $(2010,2030,2050)$ have been derived, using 
the methodology described in Dixon and Rimmer (2002). This entails inserting the forecast values for some key economic variables into the model calibration data, to identify a hypothetical general equilibrium state in the future.

Since we are working on the medium to long term, we focused primarily on the supply side: projected changes in the national endowments of labour, capital, land, natural resources, as well as variations in factor-specific and multi-factor productivity.

Most of these variables are "naturally exogenous" in CGE models. For example, the national labour force is usually taken as a given. In this case, we simply shocked the exogenous variable "labour stock", changing its level from that of the initial calibration year (1997) to some future forecast year (e.g., 2030). In some other cases, we considered variables, which are normally endogenous in the model, by modifying the partition between exogenous and endogenous variables.

We obtained estimates of the regional labour and capital stocks by running the Global-Cubed (G-cubed) model (McKibbin and Wilcoxen, 1998), whereas estimates of land endowments and agricultural land productivity have been obtained from the Integrated Model to Assess the Global Environment (IMAGE) model version 2.2 (IMAGE, 2001). A rather specific methodology was adopted to get estimates for the natural resources stock variables. As explained in Hertel and Tsigas (2002), values for these variables in the original GTAP data set were not obtained from official statistics, but were indirectly estimated, to make the model consistent with some industry supply elasticity values, taken from the literature. For this reason, we preferred to fix exogenously the price of the natural resources, making it variable over time in line with the GDP deflator, while allowing the model to compute endogenously the stock levels. 
By changing the calibration values for these variables, the CGE model has been used to simulate a general equilibrium state for the future world economy. This is the benchmark for all subsequent exercises. Therefore, this benchmark corresponds to the case in which no economic impacts of climate change have taken place, whereas the counterfactual scenarios consider the effects generated by one or more impacts. Note that there is no explicit dynamics in the model and the simulation exercises are comparative static.

\section{Input data and models}

\section{Sea level rise}

We evaluate the impacts of sea level rise in the 16 regions of GTAP-EF. For each region, Table 2 (second column) presents estimates of the potential dryland loss, in the absence of any protection intervention. Our main source of information is the Global Vulnerability Analysis (Hoozemans et al., 1993), complemented with the estimates of Bijlsma et al. (1996), and the model of coastal protection of Fankhauser (1994). Combined as described in Tol (2002), these data specify, per country, the amount of land lost due to a sea level rise of one metre. Land loss is assumed to be linear in sea level rise. It is worth mentioning that the data proposed represent just an ideal and highly simplified picture. At present there is high uncertainty concerning on the one hand sea level rise processes themselves, particularly at the local scale (for instance, scientists are still debating if and how the Mediterranean responded to global warming in the last decades, apparently its level is not rising as its increasing salinity seems to compensate thermal expansion); on the other hand the measure and forecast of their effects on coastal areas as determined by complex interactions between eustatism, geological and anthropic subsidence, tectonic 
movements, pressure differential of water and ice masses, which are not yet fully understood.

\section{Tourism}

The impacts of climate change on tourism are based on the Hamburg Tourism Model (HTM), version 1.2 (Bigano et al,, forthcoming). HTM is an econometric simulation model, estimating the number of tourists by country, the share of international tourists in total tourists, and tourism flows between countries. The model is calibrated for 1995. The number of tourists is determined by population and economic growth. The share of international tourists is larger in richer countries, as well as in those countries that are very hot or cold. Poorer countries and countries that are very hot or very cold are also less attractive to foreign tourists. The scenario for population growth, economic growth, and global warming is the Intergovernmental Panel on Climate Change Special Report Emission Scenario (IPCC SRES) A1B (Nakicenovic and Swart, 2001 - see appendix). The regional warming pattern is the average of 14 Global Circulation Models (GCMs) from the Country Specific Model for Intertemporal Climate (COSMIC) (Schlesinger and Williams, 1998).

\section{Including Impacts in the CGE Model}

To model the specific effects of climate change, we run a set of simulation experiments, by shocking specific variables in the model, depending on the scenario considered. Four different simulation exercises are compared: sea level rise "alone", tourism "alone", sea level rise and tourism combined, and an additional simulation on tourism alone, in which the effects of sea level rise on tourism destination are disregarded.

Sea Level 
This simulation considers a "no-protection" scenario: we assume that no defensive expenditure takes place, so that some land is lost in terms of productive potential, because of erosion, flooding and salt water intrusion. This case can be easily accommodated in the model by exogenously reducing the endowment of the primary factor "land" in all countries, in variable proportions.

\section{Tourism}

This scenario considers the effects of climate change on tourism in isolation or, equivalently, the effects on tourism associated with full protection of coastal areas. The shocks are computed as variations in the domestic expenditure for market services, accounting for higher (lower) expenditure on recreational activities, hotels and restaurants, generated by more (less) tourists in a country. These shocks are imposed as exogenous shifting factors in demand patterns. In addition, national incomes are also modified in order to account for the extra revenue, available for consumption, brought about by tourists.

\section{Sea Level and Tourism}

In this simulation exercise the joint effects on tourism and sea level are considered. Consequently, a simultaneous change in land endowments, consumption patterns and available national income is imposed.

However, changes in tourism flows are not the same as those considered in the "tourism alone" case. This is because the direct impact of sea level on tourism destinations is taken into account.

Nonetheless, except for some noteworthy exceptions (Canada (CAN), Western Europe (WEU) and Former Soviet Union (FSU)) changes in tourism flows are not very significant (the difference is lower than $4 \%$, see Table 1 ). 
$>>>$ PLEASE INSERT TABLE 1 ABOUT HERE $<<<$

\section{The "diagnostic" simulation on tourism}

This simulation amounts to imposing to the CGE model exactly, but only, the same shocks on market services demand of the disjoint sea level and tourism simulation. As these shocks are slightly different from those of the "tourism alone" simulation, it is necessary to isolate the role of interactions of effects in the joint shock exercise from that played by the difference in the starting points.

\section{Results}

In this section, simulation results for the year 2050 are reported and commented, in terms of variation from the no-climatechange baseline equilibrium. Results for other reference years are qualitatively similar.

\section{$\underline{5.1 \text { Sea level rise }}$}

Table 2 shows the effects of sea level rise in the absence of protection intervention, based on a uniform increase of $25 \mathrm{~cm}$.

The fraction of land lost is quite small in all regions. The highest losses affect those areas characterised by a higher proportion of coastal zones over their total land or by more vulnerable coastal zones: South East Asia (SEA), South Asia (SAS) and the Rest of the World (ROW), including basically all small island states (losing, respectively, $-0.839 \%,-0.396 \%$ and $-0.167 \%$ of their dry land).

The value of the land lost is large in absolute terms, but quite small if compared to GDP. Generally, developing regions experience direct losses higher than those of developed countries, because agriculture contributes with a higher share to 
the production of income in their economies and land is relatively more valuable.

In terms of general equilibrium effects, GDP falls in all regions. The decrease is relatively high in SEA and SAS.

The overall mechanism at play is clearly identifiable: land loss is a direct resource shortfall, that is, a negative economic shock, which reduces income and consumption levels. At the same time the value of primary resources tends to fall, with the exception of the resource "land", which is getting scarcer (Table 3).

Table 2 highlights two other interesting aspects. GDP losses in developing countries (Asian, African and Latin American countries, with the exception of China), are lower than the direct cost of land lost, whereas the opposite occurs in most developed countries (here the exception is Canada). In some cases (e.g. Japan and Korea (JPK) and USA) GDP losses are one order of magnitude larger than direct costs. Furthermore, there is no simple relationship between environmental impact and economic impact. For instance, JPK undergo a relatively high land loss, but their loss of GDP is the second smallest. China (CHI), on the contrary, has a small relative amount of land lost, but the third highest cost in terms of GDP.

Capital flows, international trade and substitution effects interact to determine the final result. The international allocation of investments is driven by the relative price of the capital in each country. The higher the capital return, the higher the share of international investments flowing into a country, with implications in terms of regional GDP variations, since investment is one component of GDP.

In turn, changes in the price of capital services are determined by two overlapping, and opposite, effects. On one hand, the negative shock lowers the value of national resources, including capital. On the other hand, economies try to substitute land with 
capital. Capital supply is fixed in the short run, though, and the higher demand for capital translates into higher capital returns.

The fall in the relative price of capital services is particularly strong in ROW, CHI, SEA and SAS (Table 3) with consequent investment outflow. This contributes to the fall in GDP.

International trade also matters, through its effects on the terms of trade. In particular, two main effects are at work here (see Table 4): higher world prices for agriculture benefit netexporters of agricultural goods (roughly concentrated in the developed world with countries like e.g. USA, Australia (in ANZ), CAN, some European countries (in WEU) and FSU), whereas lower prices for oil, gas, coal, oil products, electricity, energy-intensive industries harm the net-exporters of raw materials and energy products (broadly speaking developing regions, but also the FSU).

Finally, primary factor substitution possibilities within economic systems are also important. Labour, capital and energy substitute for the land loss. At the same time, overall economic activity falls. Note that in some regions, mostly developed, the former effect dominates. This can be noticed by observing Table 2 where $\mathrm{CO}_{2}$ emissions increase, despite the fall in GDP (e.g. in ANZ, JPK, CAN).

$>>$ PLEASE INSERT TABLE 2 ABOUT HERE $<<<$

$>>$ PLEASE INSERT TABLE 3 ABOUT HERE $<<<$

$>>$ PLEASE INSERT TABLE 4 ABOUT HERE $<<<$

\section{$\underline{5.2 \text { Tourism }}$}


The impacts described here are derived by looking at tourism alone, assuming away the effect of sea level rise on the relative attractiveness of tourist destinations.

\section{Demand and Prices}

The general equilibrium effects on endogenous demand have the same signs as the exogenous shocks. With no exception, the transmission of the shock through the economy reinforces the original shock. In equilibrium, changes in demand are on average $50 \%$ larger than the original shocks. The largest relative change (204\%) occurs in FSU where, however, the smallest absolute changes take place. ${ }^{i i}$

In terms of production, the shocks have, with no exceptions, a direct effect on the production of Market Services. Generally speaking, there are inverse effects on the production of all other goods and services which derive directly from the endogenous counterbalancing variation in the demand of all other goods and services introduced in order to keep the economy in equilibrium. iii $^{\text {ii }}$

In terms of magnitude, effects are proportional to the size of the original shock: tiny in the case of the productive sectors in FSU, sizeable in the case of ROW and to a lesser extent, JPK, Central America (CAM) and Middle East (MDE). CHI on the other hand, which undergoes the second highest shift in demand of Market Services, (more consistent than MDE or CAM), experiences a very limited effect on output and GDP. WEU experiences important reductions in the production of energy and energy intensive goods, stronger than the direct positive effect on market services' output.

As to the prices of goods and services ${ }^{\text {iv }}$, the prices of market services follow the shocks in all countries but CAN. The patterns 
for the remaining sectors are not so clear-cut. In general (with the exception of Canadian energy and energy intensive goods, bar gas), the effects on agricultural products' prices display signs opposite to those of the shocks, while the effects on all other goods and services' prices display the same as those of the shocks. The effect on fisheries is mixed. Prices absorb most of the shocks, as the magnitude of their changes is in general larger than the magnitude of production changes.

Primary factors

In terms of primary factor prices (see Table 6), in general there is a concordance of sign between price changes and the shocks for all factors but land. Since market services is a labour-and (to a lesser extent) capital-intensive sector, one would expect that the price of these two factors would increase (decrease) in presence of a positive (negative) shock on tourism demand. This pattern clearly takes place in all regions but CAN, with the sole exception of land. Indeed $\mathrm{CAN}$ is the only region experiencing a (slight) decrease in GDP (in value term) even in the presence of an increase in tourism flows (see further). This negative aggregate effect is prevailing and adversely affects demand and thus price of capital and labour. In accordance with all the regions with a negative impact on GDP, Canadian land price increases. This is due to a demand re-composition favouring agricultural products. In WEU the positive demand and subsequently GDP shock (in value and quantity) increases the price of all production factors including land.

Welfare effects, capital flows and terms of trade

In welfare terms, the effects on nominal GDP are one order of magnitude larger than the effects on real GDP and, in general, consistent with the shocks (see Table 5). The only exception is CAN, worse off after the shocks notwithstanding the increase in demand. In quantity terms, the discrepancy between shocks and 
GDP is slightly more pronounced: JPK actually experiences an overall decrease in production, hence its increase in GDP value derives from the facts that goods produced by this region become more expensive. In SAS and MDE the reverse happens: these regions increase their production, but their goods now command lower prices.

In order to understand these results, one must take into account at least three factors.

First, direct income transfers play an obvious direct role on welfare of the receiving countries: the fact that the income inflow does not result in an increase in GDP in the case of CAN can be due to the relatively small magnitude of the transfers accruing to this country, coupled with the adverse effect of other factors.

A second factor is the reaction of capital markets to the sum of these shocks. In each region, the price of capital, and hence, its return, is influenced by the pressures exerted on factors' demand by the re-composition in the output mix following the change in the demand structure of the internal market. Capital being the only internationally mobile production factor, it moves from region to region in response to the changes in its relative price. In the case under scrutiny, regions suffering a negative shock generally experience an outflow of foreign investments (the returns they offer decrease), while countries where the demand shock is positive face the opposite financial prospects (increased capital inflows, increased returns). USA, FSU and North Africa (NAF), notwithstanding the absolute decrease in returns, experience an increase in capital inflows. This can happen if in relative terms they still offer higher returns than other regions. Note however that, in the case under scrutiny, the correspondence between capital flows and changes in GDP is not so clear-cut as in the case of sea level rise. In particular, GDP 
falls in some regions attracting capital flows (USA, FSU and NAF).

Third, an important role is played by the way the model conciliates the demand shocks with budget balance and Walras' law. Note that the model generates endogenously variations in the demand of all other goods and services in order to shift the world economy to a true alternative general equilibrium. These compensating demand variations may lead to variations in aggregate indexes, such as GDP, well in excess of the original exogenous demand shocks.

A potentially important factor that may help explain the variations in GDP is the relative strength of a given region on the world market, as expressed by its terms of trade. However, everywhere but in SAS their role is overshadowed by the effect of income transfers. Changes in terms of trade mimic the changes in Market Services' demand ${ }^{\mathrm{v}}$.

In JPK, the joint effect of improved terms of trade, positive income transfers and large capital inflows results in an increase of GDP notwithstanding the decrease in overall production.

\section{Carbon Emissions}

Finally, as far as $\mathrm{CO}_{2}$ emissions are concerned, there is an overall, inverse correspondence between sign of the shocks and sign of the effects with the exception of FSU and China (see last column of Table 5). The explanation is that the Market Services sector is not an energy-intensive one, and hence there is an inverse correlation between its level of activity and $\mathrm{CO}_{2}$ emissions. Since most shocks are negative, at first glance one would then conclude that climate change, at least in the case of its direct impacts on tourism, induces a perverse effect by shifting the economy to more energy-intensive, and hence polluting sectors. This conclusion is however not granted because the results cannot provide a complete picture of the 
phenomenon. The shift towards cleaner industries in CAN, WEU and JPK can well counterbalance the effect just described. Moreover, for modelling reasons, the effect on transport emissions (in particular those due to air transport) is completely missing from the picture. One could in fact expect important countervailing effects on $\mathrm{CO}_{2}$ emissions caused by the reshuffling of travel activities from and to world tourist destinations diversely affected by climate change.

$>>$ PLEASE INSERT TABLE 5 ABOUT HERE $<<<$ $>>$ PLEASE INSERT TABLE 6 ABOUT HERE $<<<$

\section{$\underline{5.3 \text { Joint impacts on tourism and land }}$}

In this section we describe the results of introducing joint shocks on tourist demand and land availability. This joint effect takes place through two channels. First, tourist flows, which are a function of climate and land availability at each destination, are adjusted to take into account the loss of land. Second, both the resulting adjusted shocks on domestic demand for market services and the shocks on land availability are applied to the model. In practice, a set of demand and supply-side shocks are jointly imposed.

The resulting equilibrium is characterised by three main features: the final joint effect is a compound of the outcomes of the disjoint simulations, but it is not a simple sum; there is a detectable and in some cases large interaction between the shocks impacting GDP; changes in market services demand, induced by change in tourism expenditure, are by far the most important determinant of final effects. Let us consider these features one by one in detail.

Compound of disjoint effects 
The final equilibrium in the joint simulation follows qualitatively the patterns indicated by the disjoint outcomes. Taking GDP as an example (see figure 1) it can be appreciated that two negative performances in the disjoint cases translate always in a negative performance in the joint exercise. Analogously, when a positive and a negative effect are the respective outcomes of the disjoint simulations, in the joint simulation GDP takes the sign of the bigger of the two. Moreover in 8 regions over 16 the joint GDP effect is quite close to the sum of the disjoint effects (the percent difference between the composite GDP effect and the sum of the two separate GDP effects is lower than $2 \%$ ).

\section{Appreciable interaction}

On the other hand, in many cases the final effects cannot be explained solely by "adding" the disjoint effects. Sticking to the example provided by GDP (see fig. 1), in 8 regions of 16 , the difference between the GDP effect in the joint-shock case and the sum of GDP effects in the two disjoint shock cases is larger than 2\%. For SEA, South America (SAM), MDE and CAN this difference, in absolute terms, is $4.2 \%, 8.8 \%, 33 \%$ and $75 \%$, respectively.

To understand if this difference is imputable to different initial shocks (recall that changes in tourism demand are indeed slightly different in the tourism alone and in the tourism + sea level rise simulations) or to an effective interaction between shocks, we compare the outcomes of the "diagnostic" simulation on tourism.

Figure 2 shows the percentage difference between real GDP in the joint shocks simulation and the sum of GDP outcomes obtained by the sea level and "diagnostic tourism" simulations.

This difference remains detectable (higher than $2 \%$ ) in six regions (CAN, MDE, SAM, SAS, South East Asia (SEA) and Sub 
Saharan Africa (SSA)) with a particularly sharp result for CAN and MDE highlighting an important role of shock interactions ${ }^{\text {vi }}$.

\section{Prevalence of Tourism}

Figures 2, 3 and 4 allow also to disentangle the role played by single shocks in the joint simulation. Due to the presence of shock interactions, this exploration gives just approximate indications whose reliability is inversely proportional to the relevance of the interactions themselves. Nevertheless, we have shown that in the case of GDP, which should summarise all possible economic interactions, these are quite limited in 12 out of 18 cases. Accordingly we think that the analysis of the disjoint simulations can still offer useful qualitative insights.

This analysis shows clearly that the impact of climate change on tourism expenditure largely dominates in economic terms that on the loss of productive land.

Firstly (see Figure 2), it can be noticed that real GDP changes in the "diagnostic tourism" simulation are usually larger (sometimes much larger) than those induced by sea level rise alone. As a result, the combined impact and the sum of the impacts is very similar to the impact of tourism only. The synergistic effect, that is, the difference between the combined impact and the sum of the impacts, is of the same order as the impact of sea level rise only. Figure 3 underlines this. It compares the effect of adding tourism to sea level rise to tourism only; the biases of ignoring sea level rise are small, except in CAN (-150\%), SEA (18.2\%). MDE $(-16.6 \%)$ and SAM (11\%). Figure 4 compares the effect of adding sea level rise to tourism to sea level rise only; the biases of ignoring tourism are generally larger, peaking to $-250 \%$ for JPK. This is as expected: combining a small impact and a large one does not influence the large impact, but it does affect the small impact. 
Finally, consider the behaviour of the price of land in the two disjoint simulations (see Table 7 ). The increase in the land price induced directly by land scarcity due to sea level rise is substantially smaller than that induced indirectly by changes in market services' demand relative to variations in tourism flows. We recall that in this specific case a decrease in market services' demand is partly compensated by an increase in the demand of all other goods and services including agricultural commodities with a subsequent increase in the price of the land endowment ${ }^{\text {vii }}$. This outcome is an evidence of the importance of the service sector in the total economic activity and of tourism activities in the service sector. It also shows the importance of conducting a general equilibrium exercise able to report not only direct costs, but also higher order effects.

$>>$ PLEASE INSERT FIGURE 1 ABOUT HERE $<<<$ $>>>$ PLEASE INSERT FIGURE 2 ABOUT HERE $<<<$ $>>>$ PLEASE INSERT FIGURE 3 ABOUT HERE $<<<$ $>>>$ PLEASE INSERT FIGURE 4 ABOUT HERE $<<<$ $>>$ PLEASE INSERT TABLE 7 ABOUT HERE $<<<$ 


\section{Conclusions}

This study uses a CGE model to evaluate the economic implications of two specific consequences of climate change: sea level rise and change in tourism flows. In addition to the economic evaluation proper, this exercise aims firstly to highlight the economic adjustments triggered by the initial shocks, key in driving the final result and secondly, to disentangle the role of possible interactions originated by the coexistence of different impacts. To do so, impacts have been initially considered in isolation, then jointly, and finally the respective outcomes have been compared.

As far as single impacts are concerned, the main outcome is that the final effects on GDP are quite limited, unambiguously negative in the case of sea level rise, with slight gains for Western Europe, Japan and Korea, in the case of tourism.

Sea level rise implies a GDP loss ranging from $0.1 \%$ in South East Asia to $0.0004 \%$ in Canada. These values refer to an instantaneous land loss in 2050. This would imply a yearly cost of US \$14, 8.6 and 7 millions in Western Europe, US and Japan, respectively (the three developed countries with the highest absolute losses) and of US\$142.8, 47.2 and 42 millions in South East Asia, South Asia and China, respectively (the three developing economies with the highest absolute losses).

These values are considerably lower than what predicted by the direct cost literature. Just to recall: Morisugi et al. (1995) propose an annuitised cost of roughly US\$ 3.4 billion for Japan; a yearly cost ranging from Euros 4.4 to 42.5 billion is reported for Europe by CEC (2007); US \$ 1.7 and 3.7 billion are imputable respectively to the Netherlands and Germany alone (Nicholls and Klein, 2003); Yohe (1999) reports an annuitised cost of US\$ 60 millions for the US.

These differences depend on several factors. 
Firstly, it is worth recalling that GDP is typically a flow measure. Accordingly "our" impact assessment based on GDP considers only the reduced ability of the land stock, impaired by sea level rise, to produce goods and services, and not the value of the decreased land stock itself. Secondly, in our exercise land is used only for agricultural purposes and not, for instance, as building or urban space. In other words capital losses or people displacement are not considered by the present study. These two last aspects are in fact taken into account by direct costing methods and this can produce higher cost estimates.

This said, in our exercise we anyway provided an informative comparison between direct costing and general equilibrium methodologies by contrasting the total value of land lost (thus eliminating the influence of capital and displacement costs) with the final GDP effect. The first key message we would like to convey with this study is that, considerable differences between the two methodologies still remain. In comparison with the direct costing methodology, a general equilibrium approach is able to capture substitution mechanisms and economic feedbacks, and thus all those processes able to smooth, but also to amplify an initially negative impact with distributional implication. In our case, direct costs are typically lower than impacts on GDP when terms of trade improve and vice versa. In addition, different land intensities in production systems, different degrees of ability in substituting the land lost with other production factors and capital outflows driven by reduced rate of returns re-rank countries in terms of experienced losses. This is qualitatively in line with the study of Darwin and Tol (2001) and Deke et al. (2002), even though their general equilibrium evaluation is performed for a coastal protection scenario. 
Very similar comments can be drawn upon tourism. The direct climate change impacts on tourism demand proposed by the present research are in line with the existing literature (e.g., Amelung et al., 2007, CEC (2007)). We show a penalisation of warmer countries (e.g. $-20 \%,-8 \%,-7 \%$ of tourism demand in tropical islands, Middle East and South East Asia) and an advantage for regions at the higher latitudes like Western Europe or Japan and Korea where tourism demand increases by 1.3 and $8 \%$ respectively. This is qualitatively reflected in the regional GDP performances, a pattern that is reinforced by the changes in income flows brought in or out by international tourists. Changes in the composition of demand also play a role, and occasionally higher-order economic effects dominate the first order impacts described above. Again, developing countries are more severely affected; in this case this is not due to the dependence on a vulnerable sector, but, more directly, to the magnitude of the negative shocks imposed on their economies. It is worth noting, moreover, that in this case the shocks have more substantial effects on prices than on quantities, as a comparison of real and nominal GDP changes in Table 5 clearly illustrates.

Considering impacts jointly, the key message is that effect interactions do play a role. In 6 cases out of 16 there is a detectable difference between the sum of the outcomes in the disjoint and those of the joint simulations. Indeed, as long as additional exogenous shocks are imposed, factor and good substitution possibilities in the economic system are increasingly constrained (or expanded). Thus adjustments to each of the single shocks composing the set of the joint perturbations become more (or less) costly than they would be if only one shock at a time were considered.

Finally, with this exercise, it has also been possible to determine the relative contribution of the different climate change impacts 
to the final GDP performances. In economic terms, changes in tourism flows seem to be substantially more important than land loss. The change in demand scale and demand recomposition affecting the important sector of market services is by far more relevant than the relatively small supply side shock on land which prevalently affects agricultural industries. 


\title{
Methodological Appendix
}

\author{
A Concise Description of GTAP-EF Model Structure
}

The GTAP model is a standard CGE static model, distributed with the GTAP database of the world economy (www.gtap.org).

The model structure is fully described in Hertel (1996), where the interested reader can also find various simulation examples. Over the years, the model structure has slightly changed, often because of finer industrial disaggregation levels achieved in subsequent versions of the database.

Burniaux and Truong (2002) developed a special variant of the model, called GTAP-E, best suited for the analysis of energy markets and environmental policies. Basically, the main changes in the basic structure are:

- energy factors are taken out from the set of intermediate inputs, allowing for more substitution possibilities, and are inserted in a nested level of substitution with capital;

- database and model are extended to account for $\mathrm{CO}_{2}$ emissions, related to energy consumption.

The model described in this paper (GTAP-EF) is a further refinement of GTAP-E, in which more industries are considered. In addition, some model equations have been changed in specific simulation experiments. This appendix provides a concise description of the model structure.

As in all CGE models, GTAP-EF makes use of the Walrasian perfect competition paradigm to simulate adjustment processes, although the inclusion of some elements of imperfect competition is also possible.

Industries are modelled through a representative firm, minimizing costs while taking prices are given. In turn, output prices are given by average production costs. The production functions are specified via a series of nested CES functions, with nesting as displayed in the tree diagram of figure A1.

Notice that domestic and foreign inputs are not perfect substitutes, according to the so-called "Armington assumption", which accounts for - amongst others - product heterogeneity.

In general, inputs grouped together are more easily substitutable among themselves than with other elements outside the nest. For example, imports can more easily be substituted in terms of foreign production source, rather than between domestic production and one specific foreign country of origin. Analogously, composite energy inputs are more substitutable with capital than with other factors. 


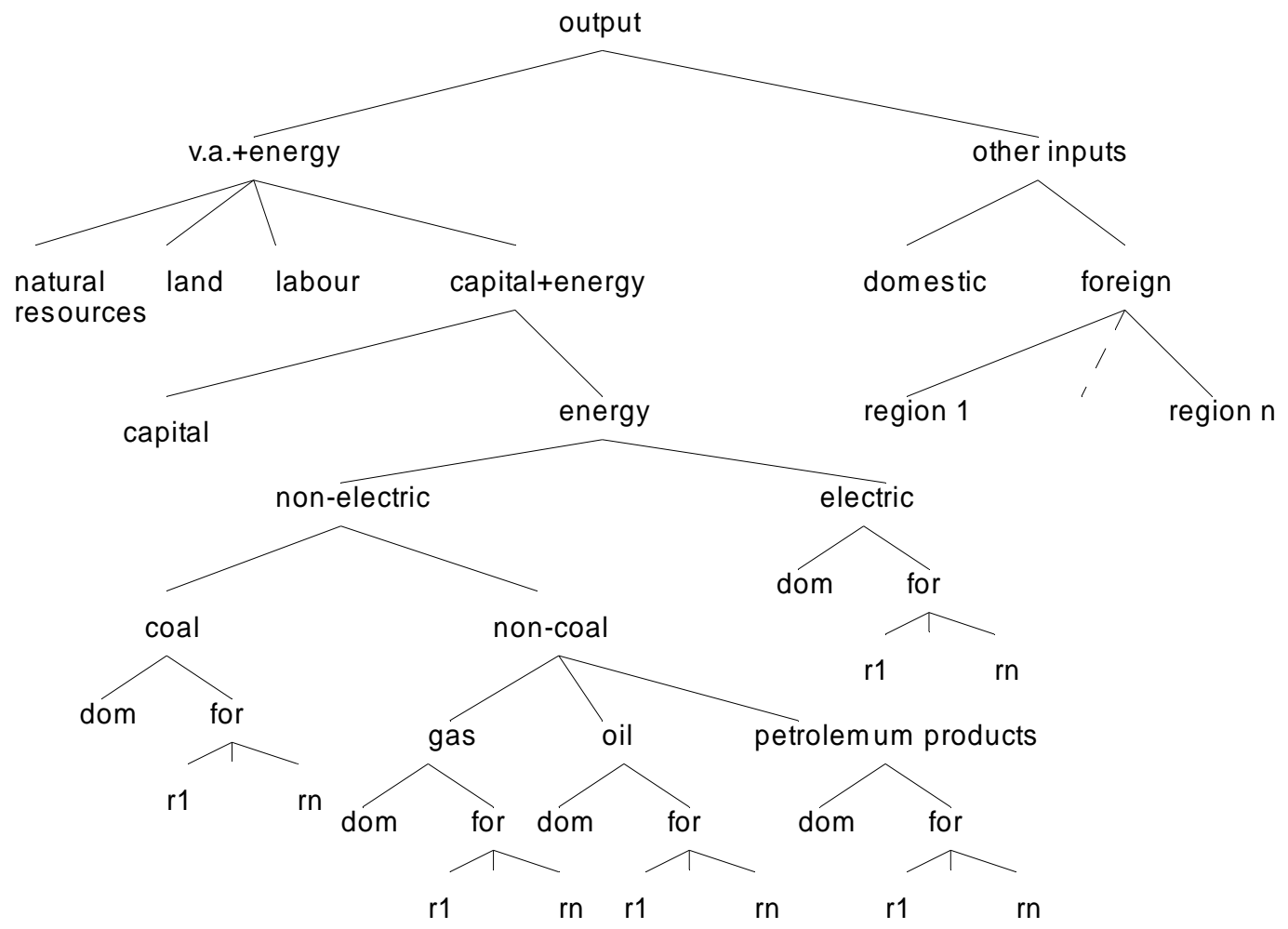

Figure A1 - Nested tree structure for industrial production processes

A representative consumer in each region receives income, defined as the service value of national primary factors (natural resources, land, labour, capital). Capital and labour are perfectly mobile domestically but immobile internationally. Land and natural resources, on the other hand, are industry-specific.

This income is used to finance the expenditure of three classes of expenditure: aggregate household consumption, public consumption and savings (figure A2). The expenditure shares are generally fixed, which amounts to saying that the top-level utility function has a Cobb-Douglas specification. Also notice that savings generate utility, and this can be interpreted as a reduced form of intertemporal utility.

Public consumption is split in a series of alternative consumption items, again according to a Cobb-Douglas specification. However, almost all expenditure is actually concentrated in one specific industry: Non-market Services.

Private consumption is analogously split in a series of alternative composite Armington aggregates. However, the functional specification used at this level is the Constant Difference in Elasticities form: a non-homothetic function, which is used to 
account for possible differences in income elasticities for the various consumption goods.

In the GTAP model and its variants, two industries are treated in a special way and are not related to any country, viz. international transport and international investment production.

International transport is a world industry, which produces the transportation services associated with the movement of goods between origin and destination regions, thereby determining the cost margin between f.o.b. and c.i.f. prices. Transport services are produced by means of factors submitted by all countries, in variable proportions.

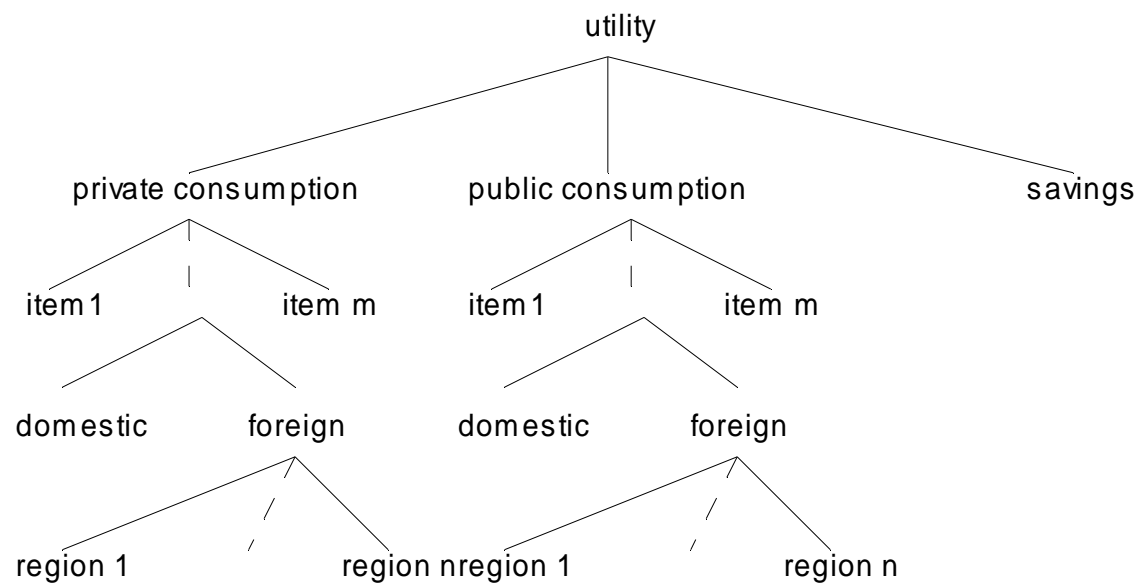

Figure A2 - Nested tree structure for final demand

In a similar way, a hypothetical world bank collects savings from all regions and allocates investments so as to achieve equality of expected future rates of return. Expected returns are linked to current returns and are defined through the following equation:

$r_{s}^{e}=r_{s}^{c} \cdot\left(\frac{k e_{s}}{k b_{s}}\right)^{-\rho}$

where: $r$ is the rate of return in region $s$ (superscript $e$ stands for expected, $c$ for current), $k b$ is the capital stock level at the beginning of the year, ke is the capital stock at the end of the year, after depreciation and new investment have taken place. $\rho$ is an elasticity parameter, possibly varying by region.

Future returns are determined, through a kind of adaptive expectations, from current returns, where it is also recognized that higher future stocks will lower future returns. The value 
assigned to the parameter $\rho$ determines the actual degree of capital mobility in international markets.

Since the world bank sets investments so as to equalize expected returns, an international investment portfolio is created, where regional shares are sensitive to relative current returns on capital.

In this way, savings and investments are equalized at the international but not at the regional level. Because of accounting identities, any financial imbalance mirrors a trade deficit or surplus in each region.

\section{A Concise Description of HTM Model Structure}

For clarity sake, we summarize here the main features of HTM. The interested Reader is however referred to Bigano et al. (2006a,b) and Hamilton et al. (2005 a,b) for a more detailed description of the model. The core of the model consists of two econometrically estimated equations, respectively for arrivals (Equation (1)) and departures (Equations (2) and (3)). In these equations the variables are, respectively:

$\begin{array}{ll}A & \text { Total arrivals per year } \\ G & \text { Land area }\left(\mathrm{km}^{2}\right) \\ T & \text { Annual average temperature }\left(\mathrm{C}^{\circ}\right) \\ C & \text { Length of coastline }(\mathrm{km}) \\ Y & \text { Per capita income } \\ D & \text { Total departures per year } \\ P & \text { Population (in thousands) } \\ B & \text { The number of countries with shared land borders } \\ H & \text { Total domestic tourist trips per year } \\ D & \text { The destination country } \\ O & \text { The origin country }\end{array}$

Arrivals are given by: 


$$
\begin{aligned}
& \ln A_{d}=\underset{0.97}{5.97}+\underset{0.96}{2.05 \cdot 10^{-7}} G_{d}+\underset{0.07}{0.22} T_{d}-\underset{2.21}{7.91 \cdot 10^{-3}} T_{d}^{2}+\underset{3.03}{7.15 \cdot 10^{-5} C_{d}}+\underset{0.09}{0.80} \ln Y_{d} \\
& N=139 ; R_{a d j}^{2}=0.54
\end{aligned}
$$

As to departure, the HTM version we used relies upon a twostep procedure. First, it estimates the total tourists generated by a given country; then it divide tourists between those that travel abroad and those that stay within the country of origin. In this way, the model provides the total number of holidays as well as the trade-off between holidays at home and abroad.

Note that in order to cover not only international tourism flows but also domestic tourism, the HTM model requires an extensive global database of the amount of domestic tourism trips per country in the base year ${ }^{1}$.

For most countries, the volume of domestic tourist flows is derived using 1997 data contained in the Euromonitor (2002) database. For some other countries, we rely upon alternative sources, such as national statistical offices, other governmental institutions or trade associations. Data are mostly in the form of number of trips to destinations beyond a non-negligible distance from the place of residence, and involve at least one overnight stay. For some countries, data in this format were not available, and we resorted to either the number of registered guests in hotels, campsites, hostels etc., or the ratio between the number of overnight stays and the average length of stay. The latter formats underestimate domestic tourism by excluding trips to friends and relatives; nevertheless, we included such data for completeness, relying on the fact that dropping them did not lead to any dramatic change.

The number of tourists that a country generates depends on the size of the population and of average income. The share of domestic tourists in total tourism depends on the climate in the home country and on per capita income. We filled the missing observations using two regressions. We interpolated total tourist

1 For most countries, the volume of domestic tourist flows is derived using 1997 data contained in the Euromonitor (2002) database. For some other countries, we rely upon alternative sources, such as national statistical offices, other governmental institutions or trade associations. Data are mostly in the form of number of trips to destinations beyond a non-negligible distance from the place of residence, and involve at least one overnight stay. For some countries, data in this format were not available, and we resorted to either the number of registered guests in hotels, campsites, hostels etc., or the ratio between the number of overnight stays and the average length of stay. The latter formats underestimate domestic tourism by excluding trips to friends and relatives; nevertheless, we included such data for completeness, relying on the fact that dropping them did not lead to any dramatic change. 
numbers, $D+H$, where $H$ is the number of domestic tourists, using:

$$
\begin{aligned}
& \ln \frac{D_{o}+H_{o}}{P_{o}}=-{ }_{0.83}^{1.67}+\underset{0.10}{0.93} \ln Y_{o} \\
& N=63 ; R_{a d j}^{2}=0.60
\end{aligned}
$$

The number of tourists may exceed the number of people, which implies that people take a holiday more than once a year. The parameters imply that in countries with an income of US $\$ 10,000$ per person per year, the average number of trips taken per person is one per year.

The ratio of domestic to total holidays was interpolated using:

(3)

$$
\begin{aligned}
& \ln \frac{H_{o}}{D_{o}+H_{o}}=-\underset{1.19}{3.75}+\underset{0.42}{0.83 \cdot 10^{-1}} \ln G_{o}+\underset{0.30}{0.93 \cdot 10^{-1}} \ln C_{o}+\underset{0.32}{0.16 \cdot 10^{-1}} T_{o}-\underset{1.11}{0.29 \cdot 10^{-3} T_{o}^{2}} \\
& +\left(\underset{0.12}{0.16-4.43 \cdot 10^{-7} Y_{o}}\right) \ln Y_{o} \\
& N=63 ; R_{a d j}^{2}=0.36
\end{aligned}
$$

The individual temperature parameters are not statistically significant from zero at the $5 \%$ level, but they are jointly significant. "Observations" for 1995 were derived from 1997 observations by dividing the latter by the population and per capita income growth between 1995 and 1997, correcting the latter for the income elasticity of (2) and (3). The income elasticity of domestic holidays is positive for countries with low incomes but falls as income grows and eventually goes negative. Qualitatively, this pattern is not surprising. In very poor countries, only the upper income classes have holidays and they prefer to travel abroad, also because domestic holidays may be expensive too. As a country gets richer, the middle income class have holidays too, and they first prefer cheap, domestic holidays. The share of domestic in total holidays only starts to fall if the lower income class are rich enough to afford a holiday abroad; with the estimates of Equation (3), this happens if average income exceeds US\$ 360,000 , a high number. However sensitivity analysis on this specification carried out in Bigano et al. (2005) confirmed the robustness of this specification.

For the total (domestic and foreign) number of tourists, the world total is $12.0 \%$ higher if we include the interpolated tourist numbers, that is, 4.0 billion versus 3.6 billion tourists. The 
observed world total includes those countries for which we have observed both domestic tourists and international arrivals. For domestic tourists only, the observations add up to 3.1 billion tourists, and 3.5 billion tourists with interpolation, a $12.1 \%$ increase.

Climate is proxied by the annual mean temperature. A number of other variables, such as country size, were included in the estimation, but these factors are held constant in the simulation. International tourists are allocated to all other countries on the basis of a general attractiveness index, climate, per capita income in the destination countries, and the distance between origin and destination. Again, other explanatory variables were included in the regression for reasons of estimation efficiency, but these are held constant in the simulation. The number of international tourists to a country is the sum of international tourists from the other 206 countries.

The core equations are estimated using 1995 data, and the model is further calibrated, so that the model almost perfectly reproduces the observations on the number of domestic tourists, international arrivals, and international departures. More convincingly, the model also reproduces international arrivals and departures for the years 1980, 1985 and 1990; for arrivals, the $\mathrm{R}^{2}$ is always greater than $93 \%$, for departures, $79 \%$; the model was calibrated independently of these observations.

The model shows that countries at higher latitudes and altitudes will become more attractive to tourists, (both domestic tourists and those from abroad). Tourists from the north west of Europe currently dominate international tourism, - the Germans and the British together account for $25 \%$ of the international tourist market - which implies that the world total of international tourist numbers initially falls because of climate change. The model also shows that the effect of climate change is much smaller than the combined effects of population and economic growth, at least for most countries.

The model does not take into account the impact of major shocks like $9 / 11$ or SARS on tourism demand and supply patterns. However, events like these are unlikely to affect the long-term trends in tourism. Furthermore, we only consider the climate-change-induced relative deviation from the trend, which implies that the details of the projected trend are not particularly important for the results. 
As mentioned, the main source of information to evaluate the impacts of sea level rise in the 16 regions represented in the economic model is the GVA (Global Vulnerability Assessment; Hoozemans et al., 1993), an update of work earlier done for the Intergovernmental Panel on Climate Change (IPCC CZMS, 1990, 1991). The GVA reports impacts of sea level rise for all countries in the world.

Dryland losses are not reported in the GVA, but they are, for selected countries, by Bijlsma et al. (1996), Nicholls and Leatherman (1995), Nicholls et al. (1995) and Beniston et al. (1998). The GVA reports people-at-risk, which is the number of people living in the one-in-1000-year flood plain, weighted by the chance of inundation. Combining this with the GVA's coastal population densities, area-atrisk results. The exponent of the geometric mean of the ratio between area-at-risk and land loss for the 18 countries in Bijlsma et al. (1996) was used to derive land loss for all other countries from the GVA's area-at-risk. This procedure introduces additional uncertainty.

Direct costs are calculated as the amount of land lost times its value. This is a crude estimate of welfare loss, but the method is standard in the literature (Turner et al. (1995) use the discounted flow of GDP per square kilometre as an indicator for land value. Broadus (1996) also uses this approach). The value of land is set at US $\$ 250,000 /$ ha in the USA, and varies with income density (GDP per area) using an elasticity of 0.53 . This elasticity is estimated using data for the states of the USA; data are taken from US DoC $(1992,1993)$.

\section{The IPCC scenarios family}

- The A1 storyline and scenario family describes a future world of very rapid economic growth, low population growth, and the rapid introduction of new and more efficient technologies. Major underlying themes are convergence among regions, capacity building, and increased cultural and social interactions, with a substantial reduction in regional differences in per capita income. The A1 scenario family develops into four groups that describe alternative directions of technological change in the energy system. 1

- The A2 storyline and scenario family describes a very heterogeneous world. The underlying theme is self-reliance and preservation of local identities. Fertility patterns across regions converge very slowly, which results in high population growth. Economic development is primarily regionally oriented and per capita economic growth and technological change are more fragmented and slower than in other storylines.

- The B1 storyline and scenario family describes a convergent world with the same low population growth as 
in the A1 storyline, but with rapid changes in economic structures toward a service and information economy, with reductions in material intensity, and the introduction of clean and resource-efficient technologies. The emphasis is on global solutions to economic, social, and environmental sustainability, including improved equity, but without additional climate initiatives.

- The B2 storyline and scenario family describes a world in which the emphasis is on local solutions to economic, social, and environmental sustainability. It is a world with moderate population growth, intermediate levels of economic development, and less rapid and more diverse technological change than in the B1 and A1 storylines. While the scenario is also oriented toward environmental protection and social equity, it focuses on local and regional levels.

\section{Acknowledgments}

We had useful discussions about the topics of this paper with Maria Berrittella, Alvaro Calzadilla, Marco Lazzarin and Hom Pant. Financial support by EC-DG Research (ENSEMBLES project) and the Hamburg University Innovation Fund is gratefully acknowledged. All errors and opinions are ours.

\section{References}

Amelung, B., S.Nicholls, and D.Viner (2007) Implications of Global Climate Change for Tourism Flows and Seasonality. J. of Tr. Res. 45: 285-297.

Berrittella, M., Bigano, A., Roson, R. and R.S.J. Tol (2006) A general equilibrium analysis of climate change impacts on tourism. Tou. Man. 27(5): 913-924.

Bijlsma, L., Ehler, C. N., Klein, R. J. T., Kulshrestha, S. M., McLean, R. F., Mimura, N., Nicholls, R. J., Nurse, L. A., Perez Nieto, H., Stakhiv, E. Z., Turner, R. K., \& Warrick, R. A. (1996) Coastal Zones and Small Islands. In: R. T. Watson, M. C. Zinyowera, \& R. H. Moss, eds. (eds.) Climate Change 1995: 
Impacts, Adaptations and Mitigation of Climate Change: Scientific-Technical Analyses -- Contribution of Working Group II to the Second Assessment Report of the Intergovernmental Panel on Climate Change, 1 edn., Cambridge University Press, Cambridge: 289-324.

Bigano, A., J.M.Hamilton, D.J.Maddison, and R.S.J.Tol (2006a) Predicting Tourism Flows under Climate Change -- An Editorial Comment on Goessling and Hall (2006). Clim. Ch. 79: 175-180.

Bigano, A., J.M. Hamilton and R.S.J. Tol (2006b) The Impact of Climate on Holiday Destination Choice. Clim. Ch. 76 (3-4): 389406.

Bigano, A., J.M. Hamilton and R.S.J. Tol (forthcoming) The Impact of Climate Change on Domestic and International Tourism: A Simulation Study. Int. Assess. J.

Bosello, F., Lazzarin, M., Roson, R. and R.S.J. Tol (2004) Economy-wide estimates of climate change implications: sealevel rise. FEEM NdL 96.04.

Broadus, J. M. (1996) Economizing Human Responses to Subsidence and Rising Sea Level. In: J. D. Milliman \& B.U. Haq, (eds.) Sea Level Rise and Coastal Subsidence. Kluwer Academic Publishers. Dordrecht, pp. 313-325.

Burniaux J-M., Truong, T.P., (2002) GTAP-E: An EnergyEnvironmental Version of the GTAP Model. GTAP Technical Paper n.16 (www.gtap.org).

CEC (2007) Limiting Global Climate Change to 2 degrees Celsius The way ahead for 2020 and beyond. Commission Staff Working Document. Brussels

Crouch G.I. (1995) A Meta-Analysis of Tourism Demand. Ann. of Tou. Res. 22, (1): 103-118. 
Darwin, R. F. and Tol, R. S. J. (2001) Estimates of the Economic Effects of Sea Level Rise. Env. and Res. Ec. 19: 113-129.

Dennis, K.C., Niang Diop, I. and R.J. Nicholls (1995) Sea Level Rise and Senegal: Potential Impacts and Consequences. J. of Coast. Res. 14: 243-261.

Deke, O., Hooss, K. G., Kasten, C., Klepper, G., \& Springer, K. (2001) Economic Impact of Climate Change: Simulations with a Regionalized Climate-Economy Model. Kiel Institute of World Economics, Kiel, 1065.

Dixon, P. and Rimmer, M., (2002) Dynamic General Equilibrium Modeling for Forecasting and Policy. North Holland.

Elsasser, H. and R.Bürki (2002) Climate change as a threat to tourism in the Alps. Clim. Res. 20: 253-257.

Fankhauser, S. (1994) Protection vs. Retreat -- The Economic Costs of Sea Level Rise. Env. and Plng A, 27: 299-319.

Fankhauser, S. and R.S.J. Tol (1996) Recent Advancements in the Economic Assessment of Climate Change Costs. En. Pol. 24 (7): 665-673.

Fankhauser, S. and R.S.J. Tol (2005) On Climate Change and Economic Growth. Res. and En. Ec. 27: 1-17.

Gambarelli, G. and A. Goria (2004) Economic evaluation of climate change impacts and adaptation in Italy. FEEM Note di Lavoro 103.04

Gössling, S. and C.M.Hall (2006a) Uncertainties in Predicting Tourist Flows under Scenarios of Climate Change. Clim. Change. $79(3-4): 163-173$.

Gössling, S. and C.M.Hall (2006b) Uncertainties in Predicting Travel Flows: Common Ground and Research Needs -- A Reply to Bigano et al. Clim. Change 79(3-4): 181-183. 
Hamilton, J.M., D.J. Maddison and R.S.J. Tol (2005a) Climate Change and International Tourism: A Simulation Study. Gl. Env. Change 15 (3): 253-266.

Hamilton, J.M., D.J. Maddison and R.S.J. Tol (2005b) The Effects of Climate Change on International Tourism. Clim. Res. 29: 255-268.

Hamilton, J.M. and R.S.J. Tol (2007) The Impact of Climate Change on Tourism in Germany, the UK, and Ireland: A Simulation Study. Reg. Env. Ch. 7 (3): 161-172.

Hertel, T.W. (1996) Global Trade Analysis: Modeling and applications. Cambridge University Press. Cambridge.

Hertel, T.W., Tsigas, M. (2002), GTAP Data Base Documentation, Chapter 18.c "Primary Factors Shares" (www.gtap.org).

Hoozemans, F. M. J., Marchand, M., \& Pennekamp, H. A. (1993) A Global Vulnerability Analysis: Vulnerability Assessment for Population, Coastal Wetlands and Rice Production and a Global Scale (second, revised edition). Delft Hydraulics. Delft.

IMAGE (2001) The IMAGE 2.2 Implementation of the SRES Scenarios. RIVM CD-ROM Publication 481508018. Bilthoven. The Netherlands.

IPCC CZMS (1991) Common Methodology for Assessing Vulnerability to Sea-Level Rise. Ministry of Transport, Public Works and Water Management, The Hague.

IPCC CZMS (1990) Strategies for Adaption to Sea Level Rise. Intergovernmental Panel on Climate Change/Ministry of Transport and Public Works. The Hague.

Jorgenson, D.W., Goettle, R.J., Hurd, B.H. and Smith, J.B. (2004) US Market Consequences of Global Climate Change. Pew Center on Global Climate Change, Washington, D.C. 
Kemfert, C. (2002) An Integrated Assessment Model of Economy-Energy-Climate - The Model Wiagem. Int. Ass. 3 (4): 281-298.

Lee, C.-C. and C.-P. Chang (2008) Tourism Development and Economic Growth: A Closer Look at Panels. Tou. Man. 29: 180192.

Lise, W. and R.S.J. Tol (2002) The Impact of Climate on Tourism Demand. Clim. Ch. 55 (4), 429-449.

Maddison, D.J. (2001) In search of warmer climates? The impact of climate change on flows of British tourists. Clim. Ch. 49: 193208.

McKibbin, W.J, Wilcoxen, P.J., (1998) The Theoretical and Empirical Structure of the GCubed Model. Ec. Mod. 16(1): 12348.

Morisugi, H., Ohno, E., Hoshi, K., Takagi, A., and Y. Takahashi (1995) Definition and measurement of a household's damage cost caused by an increase in storm surge frequency due to sea level rise. J. of Gl. Env. Eng. 1: 127-136.

Nakicenovic N. and Swart, R.J. (2000) Emissions Scenarios 2000 - Special Report of the Intergovernmental Panel on Climate Change. Cambridge University Press. Cambridge.

Nicholls, R. J. \& Leatherman, S. P. (1995) Global Sea-level Rise. In: K. M. Strzepek \& J. B. Smith (eds.) When Climate Changes: Potential Impact and Implications. Cambridge University Press. Cambridge.

Nicholls, R. J., Leatherman, S. P., Dennis, K. C., and Volonte, C. R. (1995) Impacts and Responses to Sea-Level Rise: Qualitative and Quantitative Assessments. J. of C. Res. 14: 26-43. 
Nicholls, Robert J. and Richard J.T. Klein (2003) Climate change and coastal management on Europe's Coast. EVA W. P. No.3.

Nicholls, R.J., P.P. Wong, V.R. Burkett, J.O. Codignotto, J.E. Hay, R.F. McLean, S. Ragoonaden and C.D. Woodroffe, (2007) Coastal systems and low-lying areas. In: M.L. Parry, O.F. Canziani, J.P. Palutikof, P.J. van der Linden and C.E. Hanson, (eds.) Climate Change 2007: Impacts, Adaptation and Vulnerability. Contribution of Working Group II to the Fourth Assessment Report of the Intergovernmental Panel on Climate Change. Cambridge University Press. Cambridge, UK, 315-356.

OECD (2007) Climate Change in the European Alps: Adapting Winter Tourism and Natural Hazards Management. Agrawala, S. (ed.). Paris. France.

Rosselló, J., E.Aguiló, and A. Riera (2005) Modelling Tourism Demand Dynamics. J. of Trav. Res. 44: 111-116.

Roson, R. (2003) Modelling the Economic Impact of Climate Change. EEE working paper n.9, ICTP, 2003, and presented at the EcoMod Conference, Istanbul, July 2003.

Roson, R. and R.S.J. Tol (2006) An Integrated Assessment Model of Economy-Energy-Climate - The Model Wiagem: A Comment. Int. Ass. J. 6 (1): 75-82.

Saizar, A. (1997) Assessment of a potential sea level rise on the coast of Montevideo, Uruguay. Clim. Res. 9: 73-79.

Scott, D., G.McBoyle, and M.Schwartzentruber (2004) Climate change and the distribution of climatic resources for tourism in North America. Clim. Res. 27: 105-117.

Scott, D., G.McBoyle, (2007) Climate change adaptation and the ski industry. Mitig. And Adapt. Strat. For Gl. Change 12: 14111431. 
Smith, J. B. and Lazo, J. K. (2001) A summary of climate change impact assessments from the US Country Studies Programme Clim. Ch. 50: 1-29.

Schlesinger, M.E. and L.A. Williams (1998) Country-Specific Model for Intertemporal Climate, Electric Power Research Institute, Palo Alto.

Tol, R. S. J. (2002) Estimates of the Damage Costs of Climate Change - Part 1: Benchmark Estimates. Env. and Res. Ec. 21: 4773.

Tol, R.S.J. (2005) The Marginal Damage Costs of Carbon Dioxide Emissions: An Assessment of the Uncertainties. En. Pol. 33(16): 2064-2074.

Tol, R. S. J. (2007) The Double Trade Off Between Adaptation and Mitigation for Sea Level Rise: An Application of FUND. Mitig. and Adapt. Strat. for Gl. Change 5(12): 741-753.

Tol, R.S.J., S. Fankhauser, R.G. Richels and J.B. Smith (2000) How Much Damage Will Climate Change Do? Recent Estimates. W. Ec. 1(4): 179-206.

Turner, R. K., Adger, W. N., and Doktor, P. (1995) Assessing the Economic Costs of Sea Level Rise. Env. and Pl. A, 27: 17771796

US DoC (1992) Statistical Abstract of the United States. United States Department of Commerce Bureau of the Census, Washington, D.C.

US DoC (1993) Survey of Current Business United States Department of Commerce Bureau of Economic Analysis, Washington, D.C.

Volonte, C.R. and J. Arismendi, (1995) Sea level Rise and Venezuela: Potential Impacts and Responses. J. of C. Res. 14, 285-302. 
Volonte, C.R. and R.J. Nicholls, (1995) Uruguay and Sea Level Rise: Potential Impacts and Responses. J of C. Res. 14, 262-284. Witt, S.F. and C.A.Witt (1995) Forecasting Tourism Demand: A Review of Empirical Research. Int. J. of For. 11: 447-475.

Yohe, G., J. Neumann, P. Marshall, and H. Ameden (1996) The Economic Cost of Greenhouse Induced Sea Level Rise for Developed Property in the United States. Clim. Change 32: 387 410.

Yohe, G. and M. Schlesinger (1998). Sea Level Change: The Expected Economic Cost of Protection or Abandonment in the United States. Clim. Change 38: 447-472. 
Table 1 Climate change Impacts on market-service demand reference year 2050 .

\begin{tabular}{|l|r|r|r|}
\hline & $\begin{array}{r}\text { SLR\&T } \\
\text { OU (1) }\end{array}$ & \multicolumn{1}{c|}{$\begin{array}{c}\text { TOU } \\
(\mathbf{2})\end{array}$} & $\begin{array}{l}\text { \% } \\
\text { Differ. } \\
(\mathbf{1})-(\mathbf{2})\end{array}$ \\
\hline USA & -0.866 & -0.874 & -0.870 \\
\hline CAN & 0.506 & 0.459 & 10.211 \\
\hline WEU & 0.941 & 0.883 & 6.615 \\
\hline JPK & 5.516 & 5.639 & -2.176 \\
\hline $\boldsymbol{A N Z}$ & -1.514 & -1.530 & -1.040 \\
\hline EEU & -3.124 & -3.172 & -1.485 \\
\hline & & & - \\
\hline FSU & -0.002 & -0.024 & 93.305 \\
\hline MDE & -5.951 & -5.974 & -0.385 \\
\hline CAM & -5.527 & -5.519 & 0.156 \\
\hline SAM & -1.513 & -1.521 & -0.552 \\
\hline SAS & -1.529 & -1.532 & -0.228 \\
\hline SEA & -5.412 & -5.452 & -0.728 \\
\hline CHI & -7.043 & -6.777 & 3.927 \\
\hline NAF & -3.215 & -3.204 & 0.359 \\
\hline SSA & -3.057 & -3.068 & -0.349 \\
\hline & & - & \\
& & 12.25 & \\
ROW & -12.265 & 1 & 0.115 \\
\hline
\end{tabular}

Second column: effects of sea level rise $\left(^{*}\right)$ and shifts in tourism demand jointly considered. Third column: effects of shifts in tourism demand alone. Fourth column: \% difference second and third column

* simulation for a $25 \mathrm{~cm}$. of sea-level rise in 2050 .

Values in second and third columns, expressed as \% changes w.r.t. 2050 baseline "without climate change".

Table 2 Climate-change induced sea-level rise* - reference year 2050: impacts on main economic indicators

\begin{tabular}{|c|c|c|c|c|c|c|c|}
\hline & \multirow{2}{*}{$\begin{array}{l}\text { Land } \\
\text { loss }\end{array}$} & \multicolumn{2}{|c|}{$\begin{array}{c}\text { Direct costs: } \\
\text { value of land } \\
\text { lost }\end{array}$} & \multirow{2}{*}{ GDP } & \multirow{2}{*}{$\begin{array}{l}\text { Term } \\
\text { s of } \\
\text { Trade }\end{array}$} & \multirow{2}{*}{$\begin{array}{c}\text { Invest } \\
\text { flows }\end{array}$} & \multirow{2}{*}{$\begin{array}{c}\mathrm{CO} 2 \\
\text { Emiss } \\
.\end{array}$} \\
\hline & & $\mathrm{ml} \$$ & $\begin{array}{l}\text { as } \% \\
\text { of } \\
\text { GDP }\end{array}$ & & & & \\
\hline USA & -0.052 & 121 & $\begin{array}{r}0.000 \\
2\end{array}$ & $\begin{array}{r}0.001 \\
3\end{array}$ & -0.016 & 0.015 & -0.002 \\
\hline
\end{tabular}




\begin{tabular}{|c|c|c|c|c|c|c|c|}
\hline$C A N$ & -0.002 & 72 & $\begin{array}{r}0.001 \\
7 \\
\end{array}$ & $\begin{array}{r}0.000 \\
4 \\
\end{array}$ & 0.029 & 0.032 & 0.001 \\
\hline WEU & -0.029 & 298 & $\begin{array}{r}0.000 \\
5\end{array}$ & $\begin{array}{r}0.001 \\
9\end{array}$ & -0.005 & 0.016 & -0.002 \\
\hline JPK & -0.141 & 146 & $\begin{array}{r}0.000 \\
4 \\
\end{array}$ & $\begin{array}{r}0.001 \\
8 \\
\end{array}$ & 0.006 & 0.011 & 0.025 \\
\hline$A N Z$ & -0.010 & 237 & $\begin{array}{r}0.007 \\
5 \\
\end{array}$ & $\begin{array}{r}0.000 \\
8 \\
\end{array}$ & 0.081 & 0.010 & 0.004 \\
\hline$E E U$ & -0.041 & 45 & $\begin{array}{r}0.001 \\
6 \\
\end{array}$ & $\begin{array}{r}0.004 \\
7 \\
\end{array}$ & -0.001 & -0.037 & -0.004 \\
\hline FSU & 0.000 & 0 & $\begin{array}{r}0.000 \\
0 \\
\end{array}$ & $\begin{array}{r}0.000 \\
7 \\
\end{array}$ & -0.005 & 0.010 & 0.007 \\
\hline MDE & -0.007 & 75 & $\begin{array}{r}0.001 \\
1 \\
\end{array}$ & $\begin{array}{r}0.004 \\
5 \\
\end{array}$ & 0.000 & -0.001 & 0.007 \\
\hline$C A M$ & -0.120 & 182 & $\begin{array}{r}0.004 \\
9 \\
\end{array}$ & $\begin{array}{r}0.009 \\
8 \\
\end{array}$ & 0.052 & -0.023 & -0.005 \\
\hline$S A M$ & -0.041 & 647 & $\begin{array}{r}0.004 \\
3 \\
\end{array}$ & $\begin{array}{r}0.000 \\
7 \\
\end{array}$ & 0.102 & 0.020 & 0.003 \\
\hline SAS & -0.396 & 6000 & $\begin{array}{r}0.118 \\
0 \\
\end{array}$ & $\begin{array}{r}0.064 \\
9 \\
\end{array}$ & 0.078 & -0.212 & -0.065 \\
\hline SEA & -0.839 & 14913 & $\begin{array}{r}0.147 \\
5\end{array}$ & $\begin{array}{r}0.109 \\
2 \\
\end{array}$ & -0.032 & -0.357 & -0.150 \\
\hline $\mathrm{CHI}$ & -0.091 & 579 & $\begin{array}{r}0.006 \\
3 \\
\end{array}$ & $\begin{array}{r}0.030 \\
3 \\
\end{array}$ & -0.060 & -0.236 & -0.066 \\
\hline NAF & -0.039 & 1120 & $\begin{array}{r}0.054 \\
8 \\
\end{array}$ & $\begin{array}{r}0.003 \\
6 \\
\end{array}$ & 0.012 & 0.039 & -0.012 \\
\hline SSA & -0.130 & 8869 & $\begin{array}{r}0.235 \\
9 \\
\end{array}$ & $\begin{array}{r}0.009 \\
4 \\
\end{array}$ & 0.100 & -0.029 & -0.009 \\
\hline ROW & -0.167 & 188 & $\begin{array}{r}0.022 \\
0 \\
\end{array}$ & $\begin{array}{r}0.018 \\
9\end{array}$ & -0.020 & -0.086 & -0.027 \\
\hline
\end{tabular}


change"; direct costs expressed in millions of 1997 US\$ (third column) and as \% of 2050 GDP (fourth column).

Table 3 Climate-change induced sea-level rise* - reference year 2050 : price of primary inputs by region

\begin{tabular}{|c|c|c|r|}
\hline & Land & $\begin{array}{c}\text { Labou } \\
\text { r }\end{array}$ & $\begin{array}{c}\text { Capit } \\
\text { al }\end{array}$ \\
\hline USA & 0.684 & -0.034 & -0.034 \\
\hline CAN & 0.822 & -0.013 & -0.009 \\
\hline WEU & 0.608 & -0.035 & -0.036 \\
\hline JPK & 1.132 & -0.034 & -0.035 \\
\hline ANZ & 0.967 & -0.022 & -0.028 \\
\hline EEU & 0.629 & -0.074 & -0.079 \\
\hline FSU & 0.613 & -0.038 & -0.040 \\
\hline MDE & 0.998 & -0.035 & -0.044 \\
\hline CAM & 0.806 & -0.053 & -0.059 \\
\hline SAM & 0.742 & 0.005 & 0.007 \\
\hline SAS & 1.420 & -0.285 & -0.292 \\
\hline SEA & 2.372 & -0.468 & -0.504 \\
\hline CHI & 0.521 & -0.235 & -0.260 \\
\hline NAF & 0.795 & -0.002 & 0.016 \\
\hline SSA & 1.034 & -0.055 & -0.062 \\
\hline ROW & 0.885 & -0.162 & -0.169 \\
\hline
\end{tabular}

* simulation for a $25 \mathrm{~cm}$. of sea level rise in 2050 .

All values expressed as \% changes w.r.t. 2050 baseline "without climate change".

Table 4 Climate-change induced sea-level rise $\left(^{*}\right)$ - reference year 2050: world price index by industry

\begin{tabular}{|l|c|}
\hline Rice & 0.880 \\
\hline Wheat & 0.340 \\
\hline $\begin{array}{l}\text { CerCro } \\
\text { ps }\end{array}$ & 0.455 \\
\hline $\begin{array}{l}\text { VegFrui } \\
\text { ts }\end{array}$ & 0.465 \\
\hline $\begin{array}{l}\text { Animal } \\
\text { s }\end{array}$ & 0.392 \\
\hline $\begin{array}{l}\text { Forestr } \\
\text { yoning }\end{array}$ & -0.116 \\
\hline Fishil & -0.073 \\
\hline Coal & -0.045 \\
\hline Oil & -0.035 \\
\hline
\end{tabular}




\begin{tabular}{|l|c|} 
Gas & -0.057 \\
\hline $\begin{array}{l}\text { Oil_Pct } \\
\text { s }\end{array}$ & -0.040 \\
\hline $\begin{array}{l}\text { Electric } \\
\text { ity }\end{array}$ & -0.058 \\
\hline Water & -0.044 \\
\hline $\begin{array}{l}\text { En_Int_- } \\
\text { Ind }\end{array}$ & -0.038 \\
\hline $\begin{array}{l}\text { Oth_In } \\
\text { d }\end{array}$ & 0.038 \\
\hline MServ & -0.040 \\
\hline NMServ & -0.037 \\
\hline
\end{tabular}

* simulation for a $25 \mathrm{~cm}$. of sea level rise in 2050 .

All values expressed as \% changes w.r.t. 2050 baseline "without climate change". 
Table 5 Climate-change induced changes in tourism demand - reference year 2050:

main economic indicators

\begin{tabular}{|c|c|c|c|c|c|c|c|c|c|}
\hline & $\begin{array}{c}\text { Mar } \\
\text { serv } \\
\text { dem } \\
\text { Impos } \\
\text { ed }\end{array}$ & $\begin{array}{l}\text { ket } \\
\text { ices } \\
\text { and } \\
\text { Endog }\end{array}$ & $\begin{array}{c}\text { Other } \\
\text { goods } 1 \\
\text { service } \\
\text { s } \\
\text { dem. } \\
\end{array}$ & $\begin{array}{c}\text { Income } \\
\text { transfe } \\
\text { rs }\end{array}$ & $\begin{array}{l}\text { Real } \\
\text { GDP }\end{array}$ & $\begin{array}{c}\text { Nomi } \\
\text { nal } \\
\text { GDP }\end{array}$ & $\begin{array}{l}\text { Term } \\
\text { s of } \\
\text { Trade }\end{array}$ & $\begin{array}{c}\text { Inve } \\
\text { st. } \\
\text { Flow } \\
\text { s }\end{array}$ & $\begin{array}{c}\mathrm{CO} 2 \\
\text { Emis } \\
\mathrm{s} .\end{array}$ \\
\hline $\begin{array}{l}\text { US } \\
A\end{array}$ & -0.874 & -1.259 & 1.457 & -0.365 & $\begin{array}{r}0.001 \\
5 \\
\end{array}$ & 0.857 & -0.511 & $\begin{array}{r}0.62 \\
6 \\
\end{array}$ & 0.702 \\
\hline $\begin{array}{l}C A \\
N\end{array}$ & 0.459 & 0.755 & -1.381 & 0.211 & $\begin{array}{r}0.000 \\
4\end{array}$ & 0.007 & 0.420 & $\begin{array}{r}0.11 \\
6\end{array}$ & 0.128 \\
\hline $\begin{array}{l}W E \\
U\end{array}$ & 0.883 & 1.357 & -2.287 & 0.378 & $\begin{array}{r}0.055 \\
6 \\
\end{array}$ & 0.341 & 0.331 & $\begin{array}{r}0.23 \\
8 \\
\end{array}$ & 0.064 \\
\hline$J P K$ & 5.639 & 8.096 & -14.760 & 2.779 & $\begin{array}{r}0 . \\
0.176 \\
8 \\
\end{array}$ & 4.201 & 3.768 & $\begin{array}{r}3.81 \\
0 \\
\end{array}$ & 2.106 \\
\hline $\begin{array}{l}A N \\
Z\end{array}$ & -1.530 & -2.096 & 3.475 & -0.696 & $\begin{array}{r}0.049 \\
3 \\
\end{array}$ & 0.846 & -0.063 & $\begin{array}{r}0.65 \\
4 \\
\end{array}$ & 2.012 \\
\hline $\begin{array}{l}E E \\
U\end{array}$ & -3.172 & -4.683 & 3.255 & -1.169 & $\begin{array}{r}- \\
0.106 \\
8 \\
\end{array}$ & 1.726 & -0.803 & $\begin{array}{r}- \\
0.99 \\
9\end{array}$ & 1.131 \\
\hline FSU & -0.024 & -0.073 & 0.052 & -0.011 & $\begin{array}{r}- \\
0.031 \\
1\end{array}$ & 0.543 & -0.135 & $\begin{array}{r}0 . \\
0.39 \\
0\end{array}$ & 0.004 \\
\hline $\begin{array}{l}M D \\
E\end{array}$ & -5.974 & -8.600 & 8.295 & -2.074 & $\begin{array}{r}0.003 \\
0 \\
\end{array}$ & 3.070 & -2.279 & $\begin{array}{r}1.96 \\
0 \\
\end{array}$ & 1.919 \\
\hline $\begin{array}{l}C A \\
M\end{array}$ & -5.519 & -7.980 & 7.518 & -2.387 & $\begin{array}{r}0.113 \\
9 \\
\end{array}$ & 2.644 & -1.030 & $\begin{array}{r}1.80 \\
5\end{array}$ & 1.844 \\
\hline $\begin{array}{l}S A \\
M\end{array}$ & -1.521 & -2.015 & 1.583 & -0.558 & $\begin{array}{r}0.002 \\
7 \\
\end{array}$ & 1.337 & -0.100 & $\begin{array}{r}1.16 \\
1 \\
\end{array}$ & 0.636 \\
\hline $\begin{array}{l}S A \\
S\end{array}$ & -1.532 & -1.794 & 1.102 & -0.453 & $\begin{array}{r}0.025 \\
1 \\
\end{array}$ & 0.394 & 0.596 & $\begin{array}{r}0.50 \\
7\end{array}$ & 0.404 \\
\hline $\begin{array}{l}S E \\
A\end{array}$ & -5.452 & -7.057 & 6.854 & -1.629 & $\begin{array}{r}0.032 \\
4 \\
\end{array}$ & 1.382 & -0.825 & $\begin{array}{r}0.62 \\
0 \\
\end{array}$ & 1.365 \\
\hline $\mathrm{CHI}$ & -6.777 & -8.020 & 2.731 & -1.129 & $\begin{array}{r}0.044 \\
2 \\
\end{array}$ & 0.641 & -1.127 & $\begin{array}{r}0.85 \\
4 \\
\end{array}$ & 0.149 \\
\hline $\begin{array}{l}N A \\
F\end{array}$ & -3.204 & -4.179 & 1.314 & -0.646 & 0.161 & 1.039 & -0.795 & 0.64 & 0.164 \\
\hline
\end{tabular}




\begin{tabular}{|c|c|c|c|c|c|c|c|c|c|}
\hline & & & & & 4 & & & 0 & \\
\hline $\begin{array}{l}\text { SS } \\
A\end{array}$ & -3.068 & -4.122 & 2.993 & -1.053 & $\begin{array}{r}0.007 \\
9\end{array}$ & 1.333 & -0.359 & $\begin{array}{r}0.95 \\
1\end{array}$ & 1.095 \\
\hline $\begin{array}{l}R O \\
W\end{array}$ & -12.251 & 18.984 & 17.001 & -5.990 & $\begin{array}{r}0.533 \\
0\end{array}$ & 9.864 & -7.522 & $\begin{array}{r}7.85 \\
2\end{array}$ & 4.209 \\
\hline
\end{tabular}

All values, except income transfers, expressed as \% changes w.r.t. 2050 baseline "without climate change".

Income transfers expressed as \% of GDP in 2050

Table 6 Climate-change induced changes in tourism demand reference year 2050: price of primary inputs by region.

\begin{tabular}{|l|r|r|r|}
\hline & Land & Lab & $\begin{array}{l}\text { lapit } \\
\text { al }\end{array}$ \\
\hline USA & 5.443 & -0.974 & -1.070 \\
\hline CAN & 4.463 & -0.068 & -0.125 \\
\hline WEU & 1.343 & 0.296 & 0.412 \\
\hline & - & & \\
JPK & 24.95 & & \\
\hline ANZ & 6.277 & -1.127 & -1.194 \\
\hline EEU & 7.731 & -2.404 & -2.569 \\
\hline FSU & 4.145 & -0.598 & -0.729 \\
\hline & 17.24 & & \\
MDE & 9 & -4.060 & -3.500 \\
\hline & 10.24 & & \\
CAM & 9 & -4.139 & -3.461 \\
\hline SAM & 6.656 & -1.866 & -1.745 \\
\hline SAS & 4.298 & -1.278 & -1.172 \\
\hline SEA & 9.197 & -3.068 & -2.869 \\
\hline CHI & 5.042 & -3.326 & -3.508 \\
\hline NAF & 6.912 & -1.289 & -1.026 \\
\hline SSA & 8.491 & -2.555 & -1.973 \\
\hline & & - & - \\
& 34.19 & 14.49 & 15.33 \\
ROW & 4 & 4 & 3 \\
\hline
\end{tabular}

All values expressed as \% changes w.r.t. 2050 baseline "without climate change". 
Table 7 Impacts on land prices - reference year 2050.

\begin{tabular}{|c|c|c|c|}
\hline & $\begin{array}{c}\text { SLR\&T } \\
\text { OU }\end{array}$ & SLR & $\begin{array}{l}\text { TOU } \\
\text { dia }\end{array}$ \\
\hline USA & 6.111 & 0.684 & 5.392 \\
\hline CAN & 5.213 & 0.822 & 4.362 \\
\hline WEU & 1.773 & 0.608 & 1.147 \\
\hline$J P K$ & -23.550 & 1.132 & $\begin{array}{r}24.42 \\
7\end{array}$ \\
\hline$A N Z$ & 7.239 & 0.967 & 6.232 \\
\hline EEU & 8.264 & 0.629 & 7.594 \\
\hline FSU & 4.684 & 0.613 & 4.039 \\
\hline$M D E$ & 18.199 & 0.998 & $\begin{array}{r}17.08 \\
2\end{array}$ \\
\hline$C A M$ & 11.065 & 0.806 & $\begin{array}{r}10.19 \\
8\end{array}$ \\
\hline$S A M$ & 7.378 & 0.742 & 6.589 \\
\hline SAS & 5.747 & 1.420 & 4.270 \\
\hline SEA & 11.661 & 2.372 & 9.125 \\
\hline $\mathrm{CHI}$ & 5.687 & 0.521 & 5.155 \\
\hline NAF & 7.702 & 0.795 & 6.828 \\
\hline SSA & 9.511 & 1.034 & 8.411 \\
\hline $\boldsymbol{N}$ & 35.257 & 0.885 & 34.21 \\
\hline
\end{tabular}
level rise $\left(^{*}\right)$ and shifts in tourism demand jointly considered. Third column: effects of sea-level rise $\left(^{*}\right)$ alone. Fourth column: effects of shifts in tourism demand alone in the "diagnostic" simulation.

* simulation for a $25 \mathrm{~cm}$. of sea level rise in 2050 .

All values expressed as \% changes w.r.t. 2050 baseline "without climate change". 


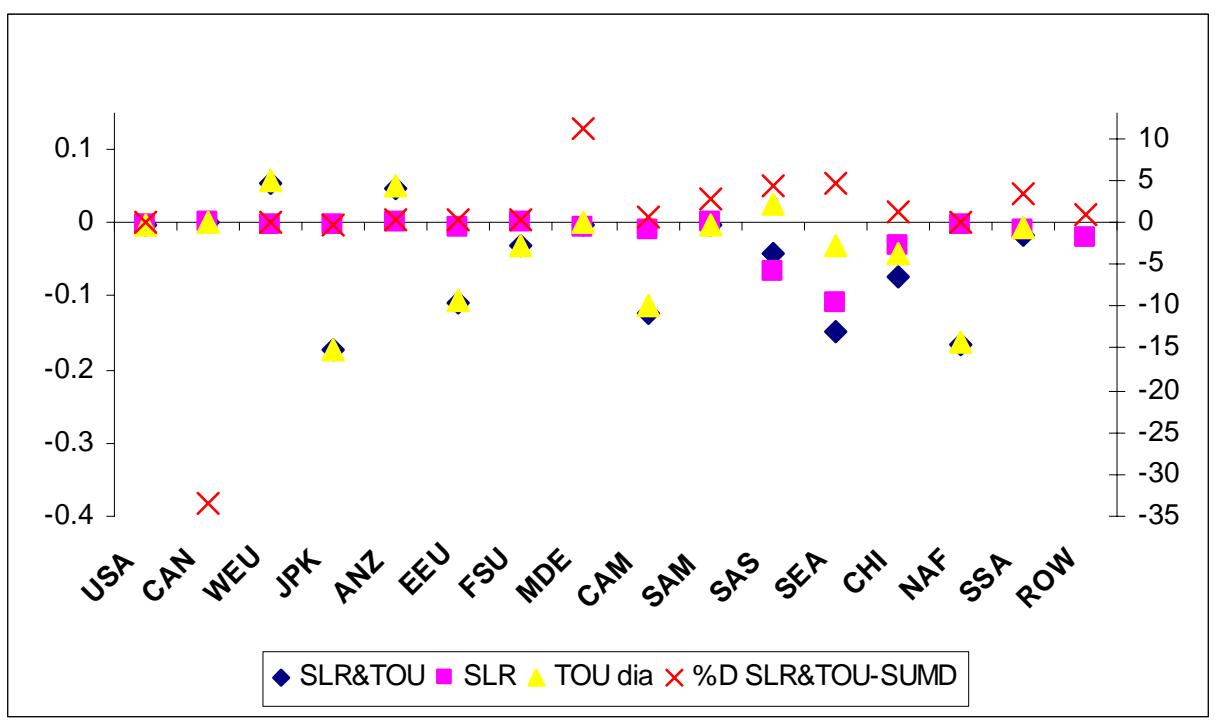

Fig.1. Comparing simulations: impacts on Real GDP (A). On the left axis read impacts on GDP (expressed as \% changes wrt 2050 baseline "without climate change") of (a) sea level rise and changes in tourism demand jointly implemented (SLR\&TOU); (b) sea-level rise (SLR), and (c) of change in tourism demand in the diagnostic simulation (TOU dia). On the right axis read (d) the percentage difference between the sum of these last two and the first $\%$ D SLR\&TOUSUM).

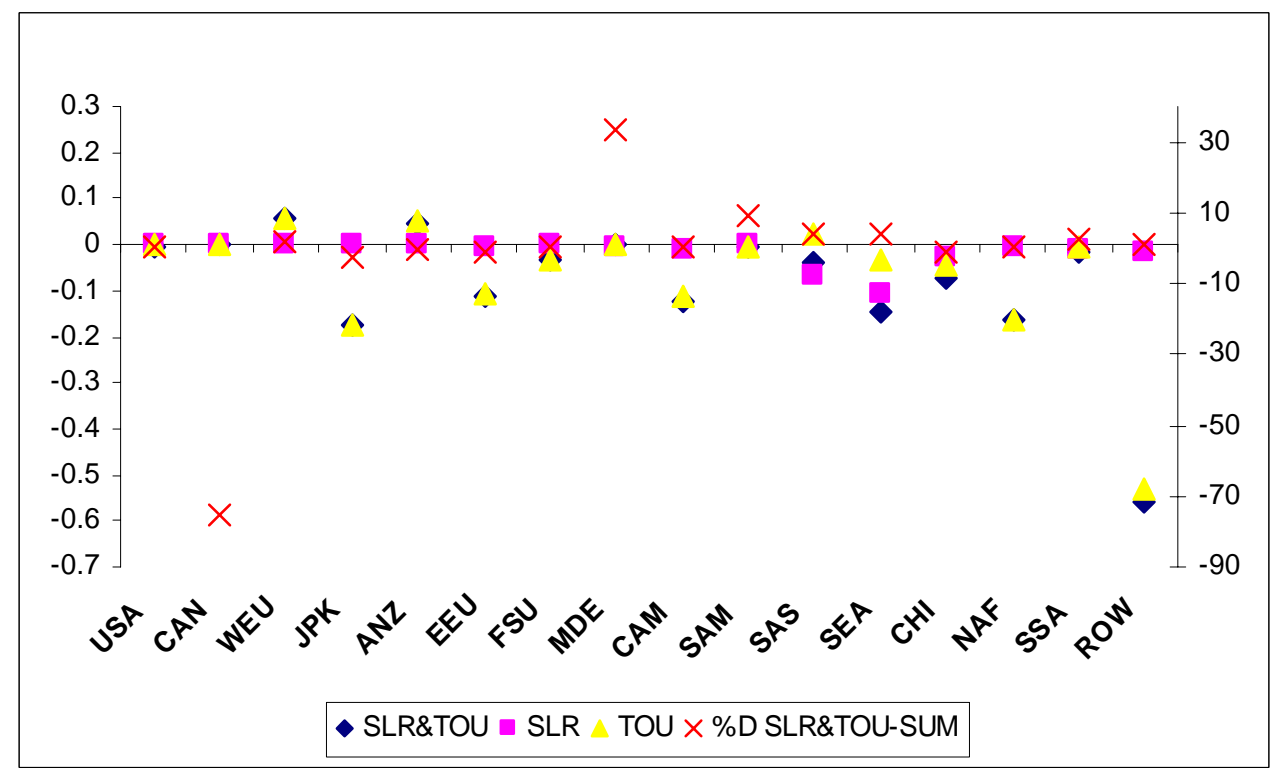

Fig. 2. Comparing simulations: impacts on Real GDP (B). On the left axis read impacts on GDP (expressed as \% changes wrt 2050 baseline "without climate change") of (a) sea level rise and changes in tourism demand jointly implemented (SLR\&TOU), (b) sea-level rise (SLR), and (c) of change in tourism demand (TOU). On the right axis read 
(d) the percentage difference between the sum of these last two and the first $(\% \mathrm{D}$ SLR\&TOU-SUM).

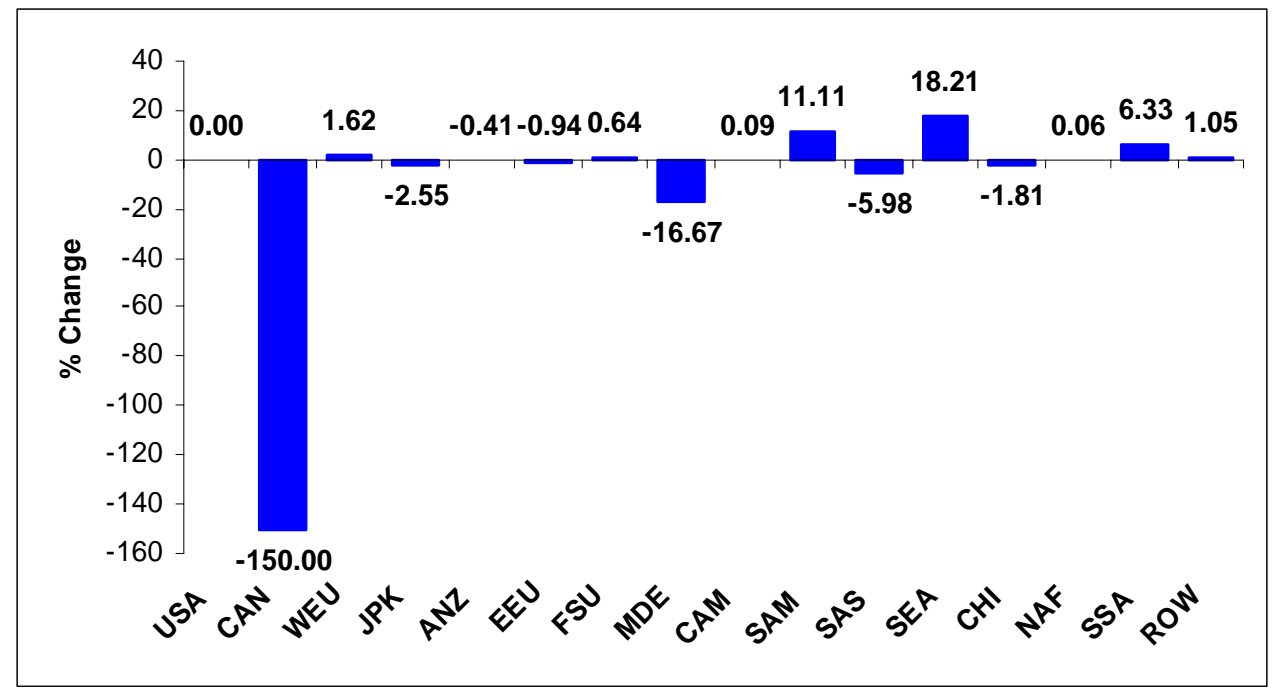

Fig. 3 Real GDP. The impact of tourism when added to the impact of sea level rise relative to the impact of tourism

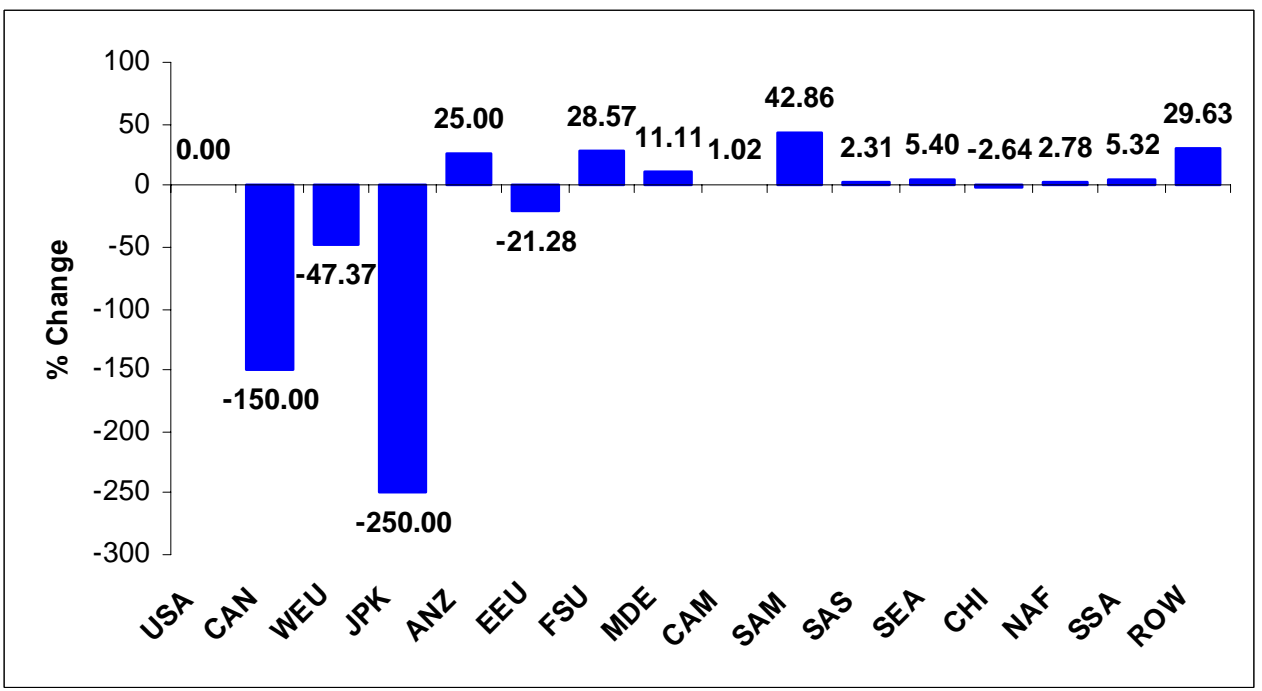

Fig. 4 Real GDP. The impact of sea level rise when added to the impact of tourism relative to the impact of sea level rise 


\section{Notes}

A more complete description of the modelling approach can be found in Roson (2003). We called the updated version GTAP-EF.

ii This is counter-intuitive: in general, one expects general equilibrium mechanisms to partially absorb the initial impacts. However, in this scenario demand shocks are coupled with income transfers, which influence demand by changing the amount of money that can be spent on goods and services, including Market Services, in the receiving regions. Note that Market Services are a luxury good.

iii However, due to the interplay of indirect general equilibrium effects this pattern is reversed in CAN, WEU and JPK (with positive effects on some of their agricultural products), ANZ, NAF and the FSU (with negative effects on most of their energy and energy intensive products).

iv For economy of space, price results are not presented here, but are available from the authors upon request

v SAS, although adversely affected in terms of direct demand for Markets Services, receives a partial indirect benefit from the new situation, by selling (expensive) inputs to regions where the tourism business improves. Although its terms of trade improve and its overall production expands, this does not yield a net gain in terms of value of GDP: capital outflows and the decrease in disposable income due to negative transfers depresses internal prices and demand to an extent that more than compensates the improved position on international markets. 
vi It is difficult to derive a "common rule" explaining these interactions, indeed joint effects can be bigger or smaller than the sum of the two disjoint effects, this depends on substitution mechanisms at play in the whole system. What emerges clearly is that effects do interact and that interactions can be quite relevant.

vii Note that land prices increase also in CAN and WEU where tourism and thus market services demand increase. But here the aggregate effect of increasing GDP prevails on the sectoral re-composition effect of demand. 